Florida International University FIU Digital Commons

6-20-2018

\title{
Employees' Responses to Positive Feedback from Customers and Managers
}

I Hsuan Tsai

itsai001@fiu.edu

DOI: $10.25148 /$ etd.FIDC006839

Follow this and additional works at: https://digitalcommons.fiu.edu/etd

Part of the Hospitality Administration and Management Commons, Human Resources Management Commons, and the Organizational Behavior and Theory Commons

\section{Recommended Citation}

Tsai, I Hsuan, "Employees' Responses to Positive Feedback from Customers and Managers" (2018). FIU Electronic Theses and Dissertations. 3794.

https://digitalcommons.fiu.edu/etd/3794 
FLORIDA INTERNATIONAL UNIVERSITY

Miami, Florida

EMPLOYEES' RESPONSES TO POSITIVE FEEDBACK FROM CUSTOMERS AND MANAGERS

A thesis submitted in partial fulfillment of

the requirements for the degree of

MASTER OF SCIENCE

in

HOSPITALITY MANAGEMENT

by

I Hsuan Tsai

2018 


\section{To: Interim Dean Michael Cheng}

School of Hospitality and Tourism Management

This thesis, written by I Hsuan Tsai, and entitled Employees' Responses to Positive Feedback from Customers and Managers, having been approved in respect to style and intellectual content, is referred to you for judgment.

We have read this thesis and recommend that it be approved.

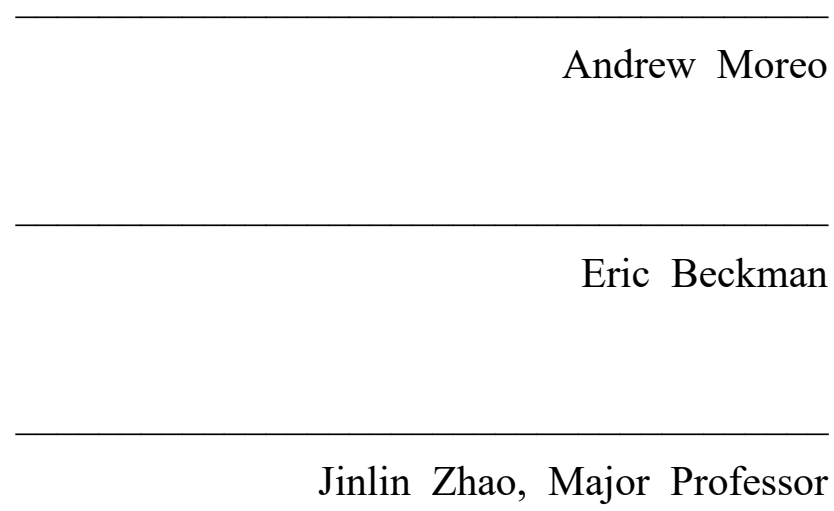

Date of Defense: June 20, 2018

The thesis of I Hsuan Tsai is approved.

Interim Dean Michael Cheng Chaplin School of Hospitality and Tourism Management

Andrés G. Gil

Vice President for Research and Economic Development and Dean of the University Graduate School

Florida International University, 2018 


\section{ABSTRACT OF THE THESIS \\ EMPLOYEES' RESPONSES TO POSITIVE FEEDBACK FROM CUSTOMERS}

\section{AND MANAGERS}

by

\section{Hsuan Tsai}

Florida International University, 2018

$$
\text { Miami, Florida }
$$

Professor Jinlin Zhao, Major Professor

The purpose of this research is to understand the impacts of positive feedback from customers and managers and the extrinsic rewards and intrinsic rewards on job satisfaction. Furthermore, this research will examine how employees in the hospitality industry react to positive feedback and to explore whether this positive feedback has practical applications to help increase employee satisfaction. A total of 500 questionnaires were distributed, 339 valid surveys from respondents with experience working in the hospitality industry were returned. The results indicated that positive feedback from customers as well as summarized positive customer feedback delivered by managers have positive relationships with intrinsic reward, extrinsic reward, and job satisfaction.

The findings suggested that positive feedback does influence employees' Job satisfaction. And this study will provide suggestions on improving employees' positive perception by applying positive feedback to increasing employees' satisfaction and further development. 


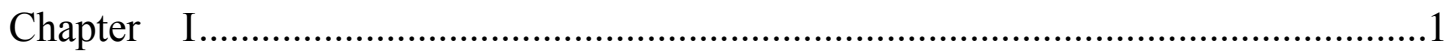

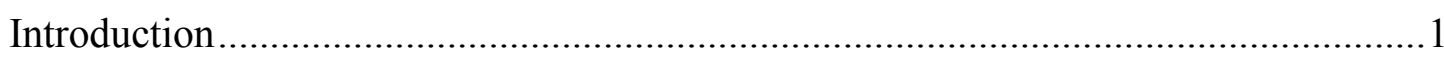

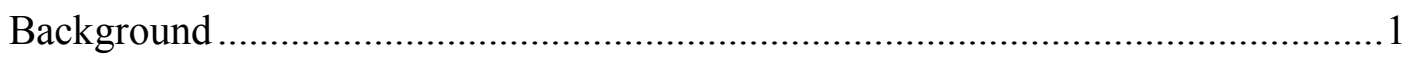

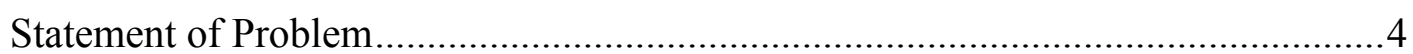

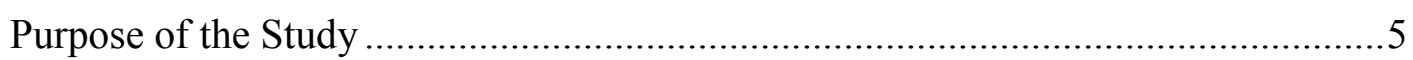

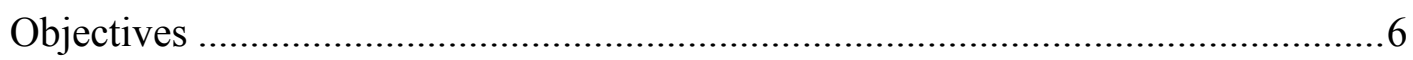

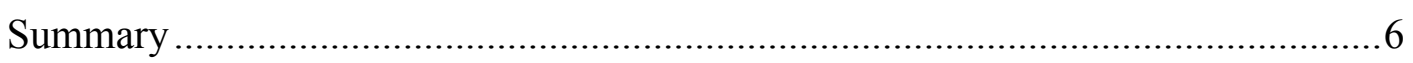

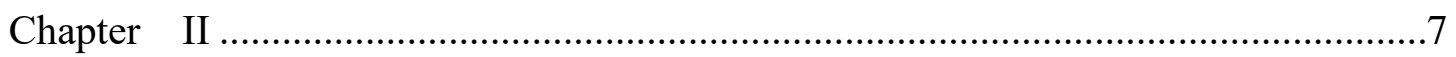

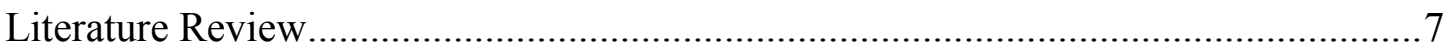

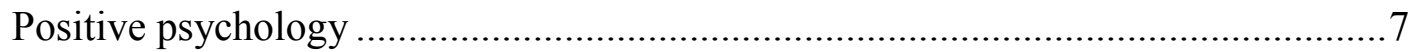

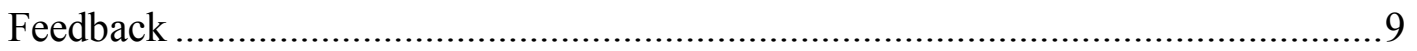

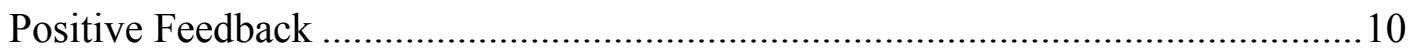

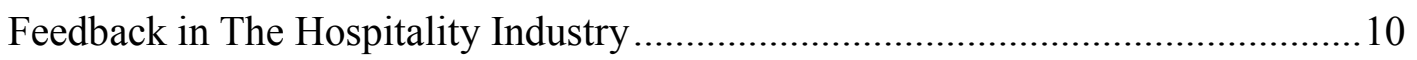

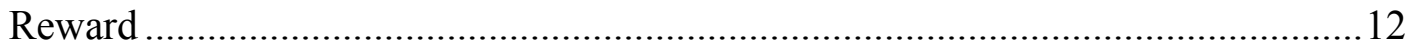

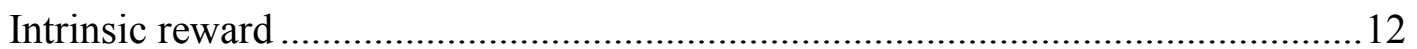

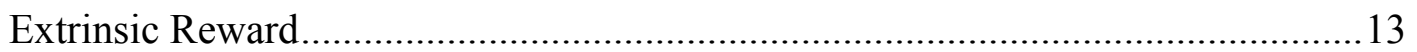

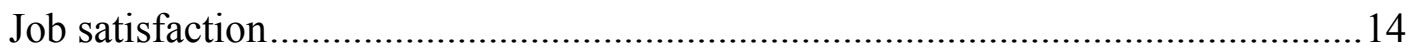

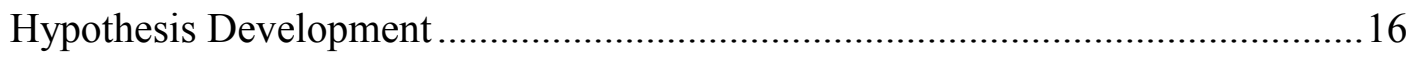

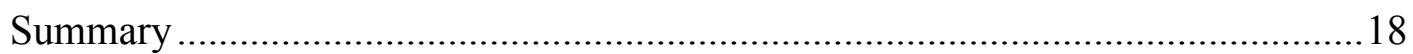

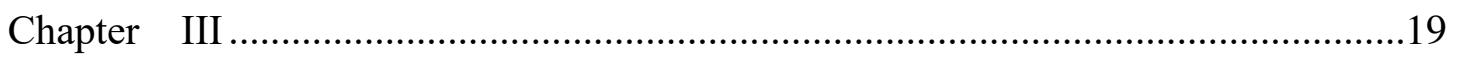

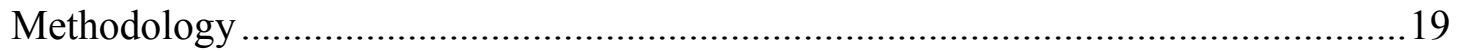

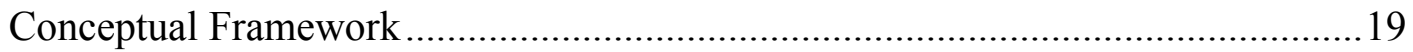

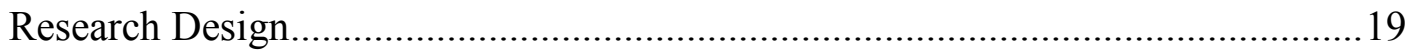

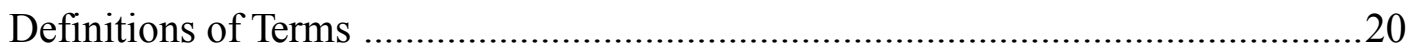

Research Instrument and Measurement ..............................................................21

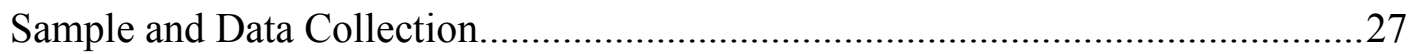

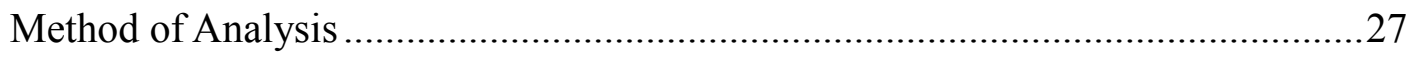

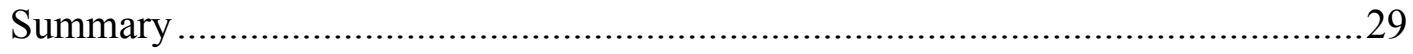




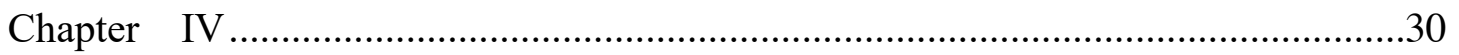

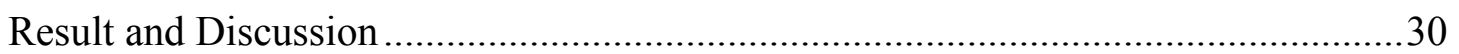

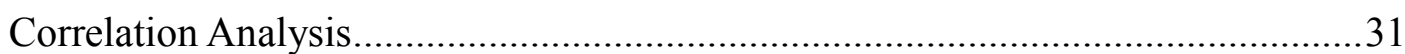

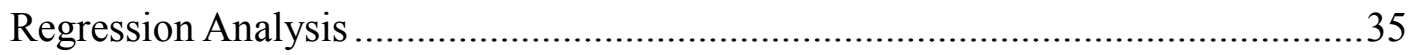

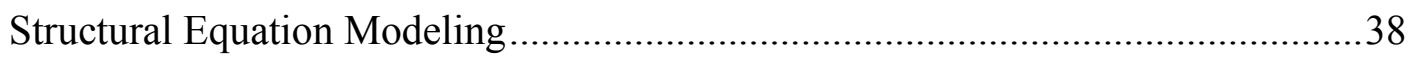

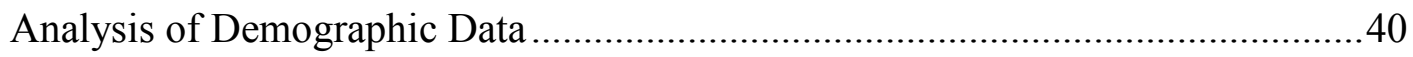

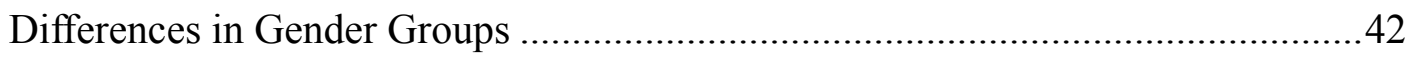

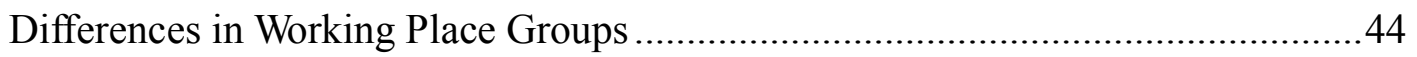

Differences in Working Schedule Groups .........................................................46

Differences in Dimension in Ethnicity Groups ...................................................48

Differences in Dimension in Education Groups ....................................................50

Differences in Dimension in Working Experience Groups ....................................54

Differences in Dimension in Scale/class of Working Place Groups ........................57

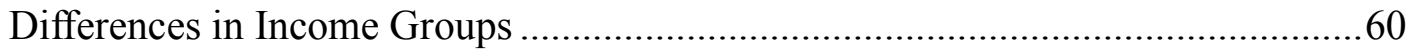

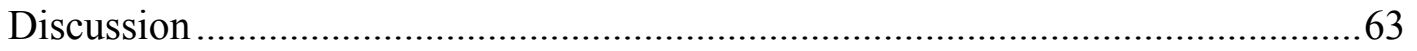

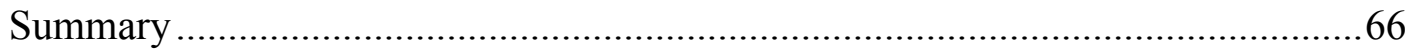

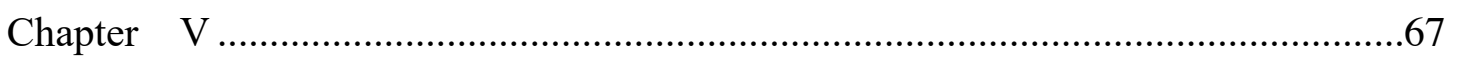

Conclusion and recommendation.....................................................................6

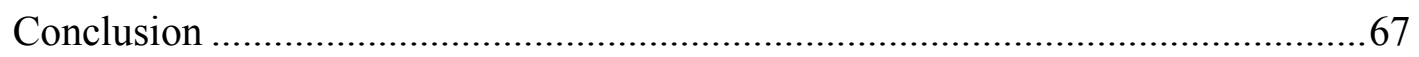

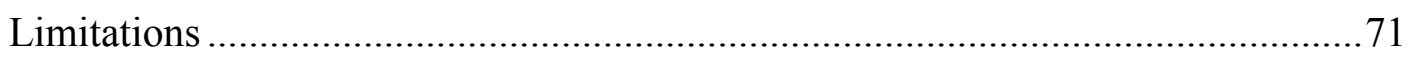

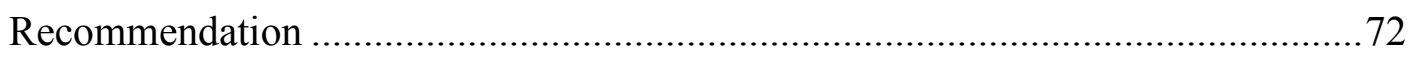

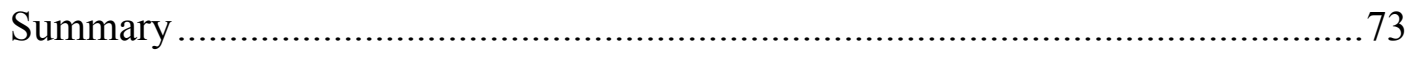

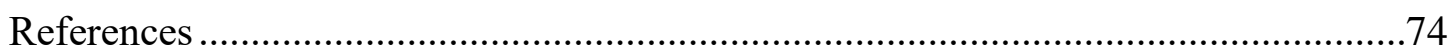




\section{LIST OF TABLES}

TABLE

PAGE

Table 3.1 Positive Feedbacks from Customers Measurement .22

Table 3.2 Positive Feedback Summarized \& Delivered by Managers Measurement ..23

Table 3.3 Intrinsic Reward from Positive Feedback Measurement .24

Table 3.4 Extrinsic Reward from Positive Feedback Measurement .25

Table 3.5 Job Satisfaction Measurement. .26

Table 4.1 Reliability analysis .31

Table 4.2 Correlation analysis. .34

Table 4.3 Regression analysis (Customers positive feedback, Managers deliver positive feedback \& Intrinsic reward) 35

Table 4.4 Regression analysis (Customers positive feedback, Managers deliver positive feedback \& Extrinsic reward) .36

Table 4.5 Regression analysis (Intrinsic reward, Extrinsic reward \& Job satisfaction)

Table 4.6 Regression analysis (Customers positive feedback, Managers deliver positive feedback \& Job satisfaction) .37

Table 4.7 (Customers positive feedback, Managers deliver positive feedback, Intrinsic reward, Extrinsic \& Job satisfaction). 
Table 4.8 Structural equation modeling......

Table 4.9 Demographic distribution

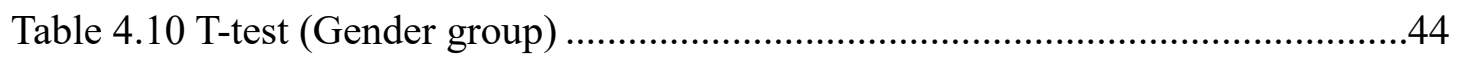

Table 4.11 T-test (Working place group) ...............................................................46

Table 4.12 T-test (Working schedule group) ….................................................48

Table 4.13 Homogeneity test (Ethnicity group) .....................................................49

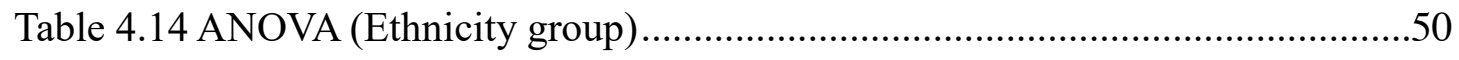

Table 4.15 Homogeneity test (Education group) ..................................................51

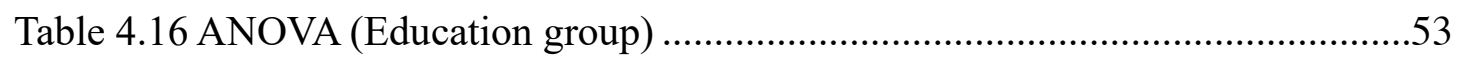

Table 4.17 Homogeneity test (experience) ........................................................54

Table 4.18 ANOVA (Experience) …..................................................................56

Table 4.19 Homogeneity test (Scale/class) .........................................................57

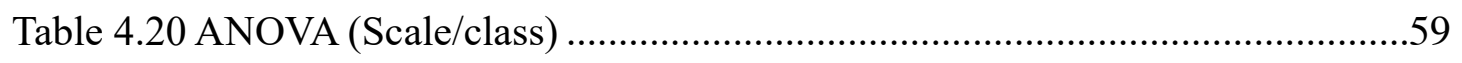

Table 4.21 Homogeneity test (Income) ..........................................................60

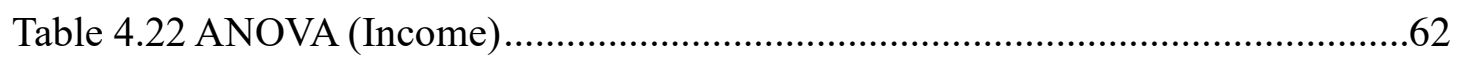




\section{Chapter I}

\section{Introduction}

\section{Background}

The hospitality industry is a customer-service oriented industry that is highly reliant on human resources. One of the characteristics of the hospitality industry is the services provided are heavily dependent on the interaction between hospitality workers and the customers. The exchange processes between them are defined in Olsen's (2008) competency model of the hospitality enterprise as the transaction of product and service, which has been deemed as "the Moment of Truth". It is important to have a moment of truth that leads to a positive result. Thus, the aim of the hospitality industry is to create unique and positive experiences for the customers, in other words, it determines the quality of the service which in turn contributes to the success of the business. As a labor-intensive industry, the organization needs to assure that the employees are willing and able to provide the customers with the services that the company expects. According to previous research, the theory of Service Profit Chain suggests that satisfied employees engender more loyal guests, higher customer satisfaction, and profitability to the firm. In addition, they tend to have higher organizational commitment, performance, lower turnover intention (Barrow, 1990; Carsten \& Spector, 1987; Judge, Thoresen, Bono, \& Patton, 2001; Heskett, Sasser \& Schlesinger, 1997). 
To be more efficient, organizations must realize that receiving feedback is not just a data-gathering exercise. Instead, the feedback received is functional in the operations of the hospitality industry through impacting the service profit chain. With this realization, they collect feedback from customers to help improve their businesses. The traditional method of feedback collection has been through written guest feedback forms which are then manually entered into their system. With the improvement of technology however, now the most often used source to obtain guest feedback is from online hotel booking websites and social networking (Prashar, 2017). Customers rate and share their own experiences to ensure the business receives detailed information. Companies now often encourage their customers to provide feedback by sending emails, through OTA websites, and written guest satisfaction survey forms in rooms or after meals (Kim \& Park, 2016). Numerous businesses use their Guest Satisfaction Survey (GSS) system to collect feedback (Prasad, Wirtz \& Yu, 2014). Sometimes in these surveys guests will praise employees and mention them by name, which some companies encourage. The effectiveness of the feedback transmission to an employee is reliant on the organization. In order for the feedback collected from different sources to be impactful on the employee, it is necessary to deliver the customers' appreciation to the employee who satisfied them.

Another theory that could explain the importance of positive feedback to an employee is Maslow's Hierarchy of Needs. According to Maslow, most of the jobs in the hospitality industry provide sufficient satisfaction in the needs of Physiological and Security needs (Maslow, 1943), in other words, the basic needs for humans to 
survive. When these basic needs are satisfied, people will pursue higher levels of psychological needs, Social and Esteem needs. The last stage of need is SelfActualization, which is the need of self-fulfillment. Therefore, receiving positive feedback is a way to achieve self-fulfillment and to enhance esteem (McLeod, 2014).

Feedback may not always lead to better performance, however, organizations could try to enhance the positive feedback with rewards systems. There are two basic forms of reward in the hospitality industry: intrinsic rewards and extrinsic rewards. According to Kreps (1997), intrinsic reward is internal motivation without external incentive and it is more a desire of natural behavior. Examples of intrinsic rewards are self-esteem, feeling of accomplishment, feeling of overcoming challenges, etc. (Wong et al., 1999). Extrinsic rewards are tangible and visible to others (Mottaz, 1985). Chiang and Jang (2008) stated that it is external motivation and incentives. Some common forms of extrinsic rewards are bonuses, tips, opportunity for promotion, advancement, etc. The purpose of a reward system is to encourage the good behavior of employees. A proper reward system would have positive impacts on employee job satisfaction (Arnett, 2002).

The question then becomes, how are feedback and rewards related to job satisfaction? Job satisfaction can be used to describe a worker's work-related attitude (Rothe, 1951; Kara, Uysal, \& Magnini, 2012). Locke (1969) described job satisfaction as a function of the perceived relationship between what an employee wants from the job and what he/she perceives the job actually offers. Kalleberg (1977) indicated that in a personal value system a person's need for fulfillment and 
dignity from work must be satisfied, the dissatisfaction could lead to a negative impact on the perceived value and lower productivity. Previous research suggests that employees with higher job satisfaction tend to have more emotions that are positive and better performance (Schlesinger, 1982). Job satisfaction is one of the most common evaluations of one's affections to the job in hospitality industry. Frontline workers interact with customers on a daily basis. Thus, they play a crucial intermediary role between the organization and customers, which will ultimately contribute to the success of the business (Arnett, 2002). Research suggests that rewards are related to employees' job satisfaction and they believe good behavior should be rewarded (Zeithaml \& Bitner, 2000; Bustamam, Teng \& Abudullah, 2014; Idemobi1, Ngige \& Ofili, 2017).

\section{Statement of Problem}

Previous research suggests that positive feedback is an important factor for student encouragement within educational theories (Conroy, Sutherland, Snyder, AlHendawi \& Vo, 2009; Mouratidis, Vansteenkiste, Lens, \& Sideridis, 2008). Meanwhile, it is suggested that positive feedback could lower turnover intention, increase organizational citizenship behaviors, and increase employee commitment in comparison to receiving negative feedback (Belschak \& Hartog, 2009). However, there is a lack of research focusing on how employees respond to positive feedback from managers and customers (Nasr, Burton, Gruber, \& Kitshoff, 2014).

In the hospitality industry, frontline staff play an important role in daily operating tasks. They interact with customers to provide the best service in order to 
please them. They are continuously making others feel good and helping them to enjoy staying in the hotel or eating the meals in a restaurant, but, how about the employees' feelings? The sentence "Happy employees equal happy customers" was often mentioned in articles and lectures (Morgan, 2015). Companies have different policies to encourage employees who did an excellent job at customer touchpoints (Barbosa-McCoy, 2016). With a successful fulfillment of the customer touchpoint, customers might leave a good comment for the staff. Is it possible to reinforce this positive customer feedback with different forms of reward to influence employees' perceptions?

There is an abundance of previous research concerning the comparison between positive feedback and negative feedback (Zapf \& Holz, 2006; Bouckenooghe, Raja \& Butt, 2013). Alternatively, this research will focus on employees' reaction to positive feedback from customers and managers' treatment of the employees when they receive this positive feedback. Nasr, Burton, Gruber, \& Kitshoff (2014) suggested future research should focus on how positive feedback impact job satisfaction and might vary from generations and cultures. Therefore, this research will put the emphasis on the investigation of the effects of positive feedback.

\section{Purpose of the Study}

The purpose of this research is to understand the impacts of positive feedback (from customers and managers) and the reward system (extrinsic rewards and intrinsic rewards) on job satisfaction. Furthermore, to have a deeper observation of how employees in the hospitality industry react to positive feedback and to find out 
whether it is important for companies to take positive feedback seriously and emphasize the practical applications to increase employee satisfaction.

\section{Objectives}

1. To identify key motivating factors for employee performance (positive feedback) resulting in positive outcome (job satisfaction).

2. To identify the reward (intrinsic and extrinsic) result that will impact hospitality staffs' positive job satisfaction.

3. To see if the manager delivering the positive feedback from customers will result in the employee having higher job satisfaction.

4. Provide suggestions to companies concerning their practices for measuring positive feedback.

\section{Summary}

This chapter briefly introduced the background and the reason to conduct the research. The aim of the research is to understand the importance of enhancing positive feedback and whether it has influences on employees' job satisfaction. The following chapter will have more explanation and clearer definitions of the theories applied in this research. 


\section{Chapter II}

\section{Literature Review}

This chapter will provide information on the theories and definitions of positive psychology, feedback, positive feedback, feedback in the contemporary hospitality industry, intrinsic reward, extrinsic reward and job satisfaction. With the basic understanding of the subjects above, hypotheses will be generated based on these theories.

The focus of this research is the investigation on the employees' perceptions of customers' direct positive feedback versus managers' delivery of summarized customer positive feedback; and the comparison between intrinsic and extrinsic rewards they received from the positive feedback. The theories of positive feedback and its delivery with the implications of intrinsic and extrinsic rewards will be examined in conjunction with job satisfaction.

\section{Positive psychology}

Fredrickson (2009) suggested that a person is more open to new information and more productive when they are in a positive mood. The Broaden and Build Theory of positive emotions (Fredrickson, 2004) explains the process and reasons for how positive emotions are transformed into productive outcomes. The potential outcomes suggested by the theory are that positive emotions could undo the arousal of lingering negative emotions, increase psychological resilience, broaden one's attention with more creativity and flexibility in new ways of thinking and acting, and bring out 
upward spirals. The broaden and build theory illustrates the functions of positive emotions in general, however, these findings could be employed to organizations in various ways.

In an organizational setting, employees with positive emotions had more perseverance and interpersonal attractions, and they often received more support from supervisors and coworkers, and were more supportive of others (Staw, Sutton \& Pelled, 1994). The theories indicate that people not only make themselves feel good by fostering positive emotions in their own lives, but also for those who are around them. Positive organizational culture and climates are suggested to have a positive correlation to the development of organizations (Glinska-Newes \& Stankiewicz, 2012), and the positive energy can be turned into employee engagement, commitment, and loyalty which increase organizational effectiveness. Additionally, positive emotion displays are suggested to have positive impacts on organizational goals, such as customer satisfaction and positive brand image (Johanson \& Woods, 2008).

Positive emotions not only impacted employees' experiences in the workplace, but also their efficiency, another important element for organizations. In organizational behavior, positive reinforcements are likely to increase the propensity for the behavior to be repeated. The positive reinforcements could be verbal praise, recognition, or other merit-based forms of bonuses (Kitterlin \& Moll, 2012). The implementation of positivity in an organization is important because people experiencing positive emotions are more helpful and friendly to others; the positive energy would be spread to others and transformed into constructive relations with 
coworkers, customers, and other stakeholders in the organization (Cialdini, 2007; Glinska-Newes \& Stankiewicz, 2012).

\section{Feedback}

Hattie and Timperley $(2007$, p.81) defined feedback as: “... information provided by an agent (e.g., teacher, peer, book, parent, experience) regarding aspects of one's performance or understanding". In other words, feedback is a result of the performance. The purpose of providing and receiving feedback are to direct or reinforce the behavior so as to meet the goal of the organization (London, Larson \& Thisted, 1999).

There are different forms of feedback which can generally be categorized into two categories, corrective (negative) and praising (positive). Feedback of performance from supervisors can cause emotional reactions that might arouse some affect-driven or extra-role behaviors and attitudes (Belschak \& Hartog, 2009). Previous research states that providing negative feedbacks is often for the purpose of addressing problems, avoiding a negative behavior, and improving the situations. However, negative feedback could possibly arouse recipients' dissatisfaction, defensive reactions, and denial (Steelman \& Rutkowski, 2004). Therefore, it is suggested that managers could frame the feedback in a positive way to the subordinates to stimulate positive affects (Belschak \& Hartog, 2009). 


\section{Positive Feedback}

Positive feedback is a confirmation and approval of a performance; it provides information that the behavior meets or exceeds expectations. Positive feedback is also known as words of affirmation, which is the language that delivers the positive messages to others (Chapman \& White, 2011). Praising one's achievement is a way to express and show words of appreciation in the workplace. Studies suggest that praise used in general vocabulary or praising one's abilities are less motivating, therefore praise should be proffered for effort-based performances and specific achievements (Weaver, 2003; Chapman \& White, 2011). According to Harackiewicz (1979) and Butler's (1987) research, positive feedback leads to higher self-reported enjoyment and more interest in doing the same activity in the comparison to no feedback.

Some researchers suggested that in behavioral patterns, people desire to receive positive feedback, as a result it is considered as a positive reinforcement (Luthans \& Kreitner, 1985). Moreover, feedback could influence one's performance due to selfefficacy and behavioral reward (Waldersee \& Luthans, 1994). Thus, accompany positive feedback with other reinforcements could enhance the feedback.

\section{Feedback in The Hospitality Industry}

The major sources of feedback in the hospitality industry are customers, supervisor or managers, peers, subordinates and performance data. Cadotte and Turgeon (1988) listed the most common complaints and compliments in the hospitality industry. Among the most common compliments related to workers' 
behavior were: helpful attitude of employees, employee knowledge and service, management's knowledge of service, responsiveness to complaints, and quantity of services. The most common channels for organizations in the hospitality industry to collect feedback are guest comment cards, customers survey, online review (OTAs, TripAdvisor, blogs and Social media webpage), online survey (approaching the customers via email or websites) and direct communication with the customer (Sugio, 2010).

The importance of the function and impact of feedback is becoming more recognized and valued by the contemporary hospitality industry. Previous research stated that feedback helps hotels that provide similar products and services discover unique competitive methods and advantages by understanding their customers' needs and expectations (Sugio, 2010). The key to making feedback useful are the actions taken after receiving feedback (Sugio, 2010). Feedback is communication between customers and the organization, but today much of the feedback is visible to other potential customers. Customers' positive feedback could impact the profitability of the organization due to word of mouth from satisfied customers and the ratings or reviews posted online that are visible to the public which could have an effect on potential customers' decision making (Radojevic, Stanisic \& Stanic, 2015).

Feedback is not just a communication channel between customer and organization, nowadays it is beginning to be valued in human resource management, especially in the labor intensive serviced-oriented industry. With the concept that one of the most valuable assets in an organization are outstanding employees, the 
relevance of feedback in an organization is being noticed and an interest in it is being taken (Mulder \& Ellinger, 2013). Scholars indicated that positive feedback from a supervisor could enhance employees' creativity and their perception of higher managerial support (Hon, Chan \& Lu, 2013). Therefore, the communication and measures taken after receiving the feedback is something to which organizations in the hospitality industry need to pay attention.

\section{Reward}

Kulhavy (1977) stated that feedback does not necessarily lead to better performance, however, combining the feedback with a reward system could help to enhance the impact of the positive feedback. Ajmal, Bashir, Abrar, Khan, \& Saqib (2015) found that intrinsic reward and extrinsic reward are important for employees to engage more in their work. Previous research also suggested that rewards have positive influence to organizations’ Total Quality Management performance (Allen \& Kimann, 2001).

The common forms of reward in the hospitality industry can be divided into intrinsic and extrinsic rewards. Scholars suggested that it is important to understand that different types of rewards have different levels of impact relating to job satisfaction (Katz \& Van Maanen, 1977).

\section{Intrinsic reward}

The definition of "intrinsic" from Oxford Dictionary of English is belonging naturally (Intrinsic, 2013, p. 481). Thus, an intrinsic reward can also be referred to as 
intrinsic motivation, which has been defined as the act of an activity that is for one's internal satisfaction instead of for the purpose of separate consequences (Ryan \& Deci, 2000). In other words, intrinsic motivation is without external incentive or recognizable rewards, it is more a desire of natural behavior (Kreps, 1997). Intrinsic reward is more about one's feelings, the increasing of an individuals' internal happiness and satisfaction. The factors of intrinsic rewards are self-esteem, a feeling of accomplishment, self-direction, a feeling of overcoming challenges, etc. (Wong et al., 1999; Mottaz, 1985).

Intrinsic reward comes from the internal perception of an individual, therefore, this type of reward does not generate direct costs and could produce the desired effect immediately (Allen \& Kimann, 2001). Intrinsic rewards provide workers in hotels a sense of accomplishment when having good performance and motivates them not only to work their best in the job but also to take on more responsibilities (Chiang \& Jang, 2008).

\section{Extrinsic Reward}

Extrinsic rewards are external motivators and incentives that are separate from the job itself (Chiang \& Jang, 2008; Ryan \& Deci, 2000). The dimensions of extrinsic reward have been divided into three categories: financial dimension (monetary rewards and job security), social dimension (interpersonal relationships) and convenience dimension (job characteristics make workers feel comfortable) (Kalleberg, 1977). Among them, the financial dimension is considered the most 
common and direct aspect when it comes to extrinsic reward (Allen \& Kimann, 2001).

Some common forms of extrinsic rewards in the hospitality industry include bonuses, tips, opportunity of promotion, advancement, etc. (Veldhoen, 2016; Chiang \& Jang, 2008). Organizations provide extrinsic rewards to their employees to elevate task performance (Mottaz, 1985; Mossbarger \& Eddington, 2003).

\section{Job satisfaction}

For decades, numerous scholars have studied Job Satisfaction (Armstrong, 2006; Aziri, 2011; George et al., 2008; Hoppock, 1935; Vroom, 1964; Roth, 1951), and it is one of the most often used constructs in research. Among the studies, the definition of job satisfaction has been concluded as a combination of psychological, physiological and environmental situations that lead to individual's attitude, positive or negative feelings toward the job.

There are a great number of both external factors and internal factors that influence an individual's job satisfaction or dissatisfaction. Moynihan and Pandley (2007) suggested that managers have great influence on job satisfaction. Rue and Byars (2003) also listed factors that affect employees' job satisfaction: working condition, perceived long-range opportunities, compensation, manager's concern, etc. One of the most notable theories used in the job satisfaction literature is The Motivation-Hygiene Theory also known as Two-Factor Theory proposed by Herzberg (1959). It was concluded that the motivating factors determining job satisfaction are the work itself, achievement, recognition, responsibility advancement and growth. 
The factors above are related to the nature of the work, which provides the sense of satisfaction to the employees. In other words, motivating factors have a greater longterm positive effect on performance. On the contrary, hygiene factors like company policies, supervision, salary, interpersonal relationship, working environment, etc. can lead to employees' dissatisfaction.

In Heskett's (1997) Service Profit Chain theory, employee satisfaction is linked to the outcome of the service provided to customers then to the customers' satisfaction, customer loyalty, revenue, and finally profitability. Furthermore, the outcome of each factor is also linked back to and influences the employees' satisfaction. Thus, organizations are taking an interest in job satisfaction due to the increasing value produced by satisfied employees (Ittner \& Larcker, 2003). Such findings are supported by the relationships found between employees' job satisfaction and customers' satisfaction, in that a satisfied employee is more willing to provide good service and sometimes displays a positive perception of the merchandise or service to be sold (Chiang et al., 2013; Bulgarella, 2005; Karatepe et al., 2006; Gelade \& Young, 2005). Therefore, employees with higher job satisfaction could increase customer satisfaction as well as profitability for the organization.

Job satisfaction has also been found to have a significant connection with employees' job performance, organizational commitment, and turnover intention (Barrow,1990; Carsten \& Spector, 1987; Judge, Thoresen, Bono, \& Patton, 2001). High turnover rate is one of the challenges for organizations in the contemporary hospitality industry due to the costs generated from recruiting, hiring, and training 
new staff. As a result, organizations are striving to reduce turnover and keep their good employees. Bouckenooghe, Raja, and Butt (2013) also indicated that job satisfaction is one of the moderators to job performance and turnover intention; the higher job satisfaction a person perceived the better performance and lower the turnover intention he/she has.

\section{Hypothesis Development}

Positive Feedback and Rewards: From the previous chapter, the employ of positive psychology in an organizational setting can result in better efficiency and can impact the workers' emotions in the workplace (Glinska-Newes \& Stankiewicz, 2012). The more positive feedback one received the higher the internal enjoyment he/she has (Harackiewicz, 1979). The internal enjoyment brought by the positive feedback were resulting from intrinsic rewards, such as self-esteem, a feeling of accomplishment, and a feeling of overcoming challenges.

Also, using external reinforcements is a way to enhance the power of the positive feedback. In the hospitality industry, nowadays, different companies have their own standard reward system. Some have clear rules for employees that received positive feedback from guests, but some do not. Some managers deliver and emphasize the positive feedback. It is assumed that the more positive feedback an employee receives, the more intrinsic and extrinsic rewards s/he would receive.

There is a lack of research on the comparison of the employees' perceptions on receiving direct customer positive feedback and manager delivered summarized customer positive feedback. Therefore, the hypotheses address the impact of direct 
customer feedback and manager delivered customer feedback on intrinsic and extrinsic rewards.

H1a: Positive feedback from guests is positively related to intrinsic rewards.

H1b: Positive feedback from guests is positively related to extrinsic rewards.

H2a: Positive feedback from guests summarized and delivered by a manager is positively related to intrinsic rewards.

H2b: Positive feedback from guests summarized and delivered by a manager is positively related to extrinsic rewards.

Reward and Job Satisfaction: In Pratheepkanth's (2011) study, the results indicated that both intrinsic reward and extrinsic reward systems have a positive impact on employees' job satisfaction. The purpose of a reward system is to encourage the good behavior of employees. A proper reward system would have a positive impact to a staff's job satisfaction (Arnett, 2002). Previous research also suggested that workers in higher positions were influence by intrinsic factors more, in comparison with those who have a lower position (Mottaz, 1985). In conclusion, the rewards resulting from positive feedback should have a positive relationship with job satisfaction. Thus, hypothesis 3 was generated based on the statements mentioned above.

H3a: Received intrinsic rewards are positively related to job satisfaction.

H3b: Received extrinsic rewards are positively related to job satisfaction.

Positive Feedback and Job Satisfaction: Positive customer feedback is a confirmation, recognition and approval of a performance, and it increases 
organizational health through positive affective climate (Kipfelsberger, Herhausen \& Bruch, 2016). It has been suggested that job satisfaction is determined by a sense of achievement, enjoyment, recognition, etc., which is considered as the motivating factors in Herzberg's (1959) Motivation-Hygiene Theory. Also it has been suggested that motivating factors have a greater long-term positive effect on employees. Meanwhile, positive feedback brings higher self-enjoyment and more interest in doing the job for workers. As a result, it is hypothesized that the more positive feedback an employee receives the higher job satisfaction he/she will have. However, there is a lack of research on the differences in employee's perception of feedback directly from the guest versus feedback summarized from a manager. Therefore, hypotheses 4 and 5 were generated.

H4: Positive feedback direct from customers is positively related to job satisfaction.

H5: Positive feedback from guests, summarized and delivered by a manager is positively related to job satisfaction.

\section{Summary}

The literature review focused on the theories and the impacts of applying positive psychology, feedback, positive feedback, feedback in the contemporary hospitality industry. The definitions of intrinsic reward, extrinsic reward, and job satisfaction provide this research a foundation to investigate the relationship between each factor. 


\section{Chapter III}

\section{Methodology}

The previous chapter illustrated the importance and potential positive influence of fostering positive psychology, feedback, and rewards systems in organizations with existing literature. In this chapter the research framework, research methods, instruments, data collection, and methodology will be discussed.

\section{Conceptual Framework}

$\mathrm{H} 4$

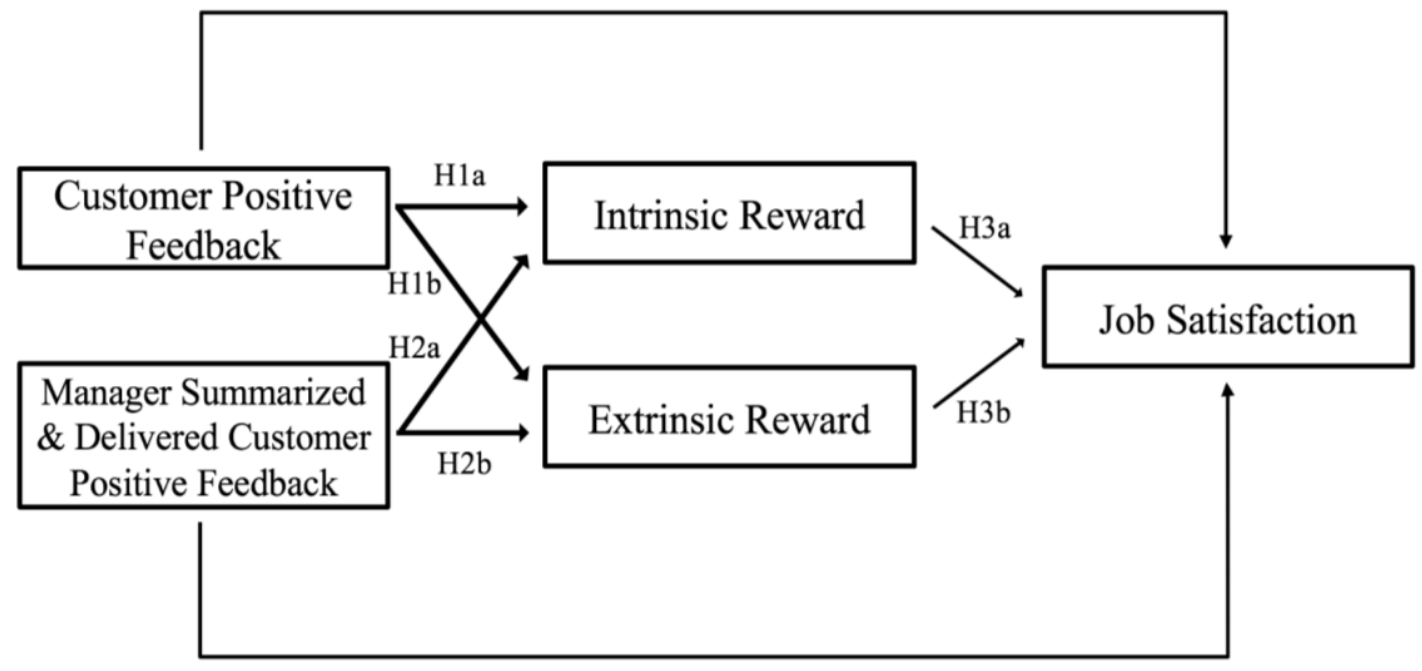

H5

Figure 3.1 Research Framework

\section{Research Design}

The aim of this research is to examine whether there are differences in the relationships between the impact of customers' positive feedback on intrinsic rewards and extrinsic rewards and the impact of managers' delivery of the positive feedback on intrinsic and extrinsic rewards employees received. In addition, how the positive 
feedback and the two types of rewards influence employees job satisfaction in the hospitality industry.

Questionnaires are a way to collect data from diverse subjects. The questionnaire utilizes scales, in the form of questions, to measure the subjects' attitudes towards a set of statements (Birmingham \& Wilkinson, 2003). Through the questionnaire, the subjects not only express their feelings but can also keep the answers anonymous (Sugio, 2010). This research is about examining individual's perception towards the aspects mentioned previously. The questionnaire was used as the data collecting tool, and the data gathered through the scales were then inputted into a statistical package for analysis. Thus, this is a quantitative research.

\section{Definitions of Terms}

Back-office employee - The employee that does not serve customers in daily operating. Such as the staff who works in engineering division, human resources, accounting department

Extrinsic Reward - External motivation and incentives such as bonuses, tips, opportunities of promotion, etc. that a person receives from getting positive feedback.

Front-line employee - The employee who has direct interactions with guests on daily basis.

Full-time employee - The employee who is usually required to work between 32 to 40 hours a week. 
Intrinsic Reward - Internal motivation and satisfaction like a sense of accomplishment, delightfulness, etc. that a person experiences from getting positive feedback.

Part-time employee - The employee who works less than 32 hours a week.

Positive Feedback - Responses provided to confirm that a person's performance and behavior meets or surpass the expectation. The formats can be positive comment, expression of gratitude, compliment, praise, or even a smile.

\section{Research Instrument and Measurement}

This research is quantitative in nature and the data was collected with a questionnaire. In accord with the literature review and the conceptual framework, the questionnaire consisted of four sections. The first two sections can each be divided into two parts. In each section, the variables were measured on a seven-point Likerttype scale varying from "strongly disagree" (1)/ "strongly dissatisfied"(1) to "strongly agree"(7)/ "strongly satisfied"(7). The total scores were be used to exam the hypotheses. The four sections of this questionnaire are:

1. Perceived positive feedback

(1). Perceived positive feedback from customers;

(2). Perceived positive feedback delivered by managers;

2. Reward from positive feedback

(1). Intrinsic rewards; 
(2). Extrinsic rewards;

3. Job satisfaction;

4. Demographic variables.

Measurement of Perceived Positive Feedbacks from Customers: This measurement was adapted from the perception of teachers' feedback scale developed by Koka and Hein (2005). There are seven items under the first part of section one. The items concern general feedback received in the hospitality industry through different forms and channels. It was measured using a seven-point Likert-type scale varying from "strongly disagree" (1) to "strongly agree" (7). The total score was used to indicate the perceived positive feedback the hospitality employees received form customers. The higher the aggregated score, the more positive feedback they received from customers.

Table 3.1 Positive Feedbacks from Customers Measurement

Items

1. I often receive praise from my customers.

2. My customers confirm that I am providing good service.

3. I often receive complimentary letters from customers.

4. Customers show their appreciation for my good service.

5. Customers smile at me when I provide good service.

6. In response to a good service encounter customers fill out a complimentary letter/ email with my name in it.

7. In response to a good service encounter customers write positive reviews online with my name in it. 


\section{Measurement of Perceived Positive Feedback Summarized and Delivered by}

Managers: This measurement was adapted from a supervisory feedback scale from Jaworski and Kohli (1991). There are six items under the second part of section one. The items examine the employees' perception of the delivery of positive customer feedback through managers. It was measured using seven-point Likert-type scale varying from "strongly disagree" (1) to "strongly agree" (2). The aggregated score was used to indicate the perceived positive feedback managers delivered for customers to the hospitality employees. The higher the total score, the more positive feedback customers provided and was delivered to the employees.

Table 3.2 Positive Feedback Summarized \& Delivered by Managers Measurement

Items

1. My manager lets me know when a customer praises me.

2. My manager praises me when customers praise me.

3. When customers provide positive feedback, my manager confirms that I provided good service.

4. My manager often delivers complimentary letters from customers to me.

5. My manager praises me in front of my co-workers.

6. My manager delivers customer appreciation to me.

Measurement of Intrinsic Reward from Positive Feedback: The measurement of intrinsic reward was adapted from Mottaz's (1985) and Allen and Kilmann's (2001) reward practice survey. This part includes seven items of intrinsic motivational rewards that an employee may perceive when he/she received positive feedback. It was measured using a seven-point Likert-type scale varying from "strongly disagree" 
(1) to "strongly agree" (7). The sum of the scores determined the intrinsic rewards the hospitality workers perceived when they received positive feedback. The higher the score, the more intrinsic rewards the employee perceived.

Table 3.3 Intrinsic Reward from Positive Feedback Measurement Items

1. I felt a sense of achievement when I received positive feedback.

2. I felt recognized when I received positive feedback.

3. I felt proud of myself when I received positive feedback.

4. The positive feedback was meaningful to me.

5. I feel capable of overcoming challenges.

6. I felt delighted when I received positive feedback

7. I felt my work was appreciated when I received positive feedback.

Measurement of Extrinsic Reward from Positive Feedback: The measurement of extrinsic reward was adapted from a reward practice survey which was developed by Allen and Kilmann (2001). This part includes seven items of extrinsic motivational rewards resulting from receiving positive feedback, and was measured using a seven-point Likert-type scale varying from "strongly disagree" (1) to "strongly agree" (7). The total score indicates the extrinsic rewards a worker of the hospitality industry perceived when they received positive feedback. The higher the score, the more extrinsic rewards the employee acquired. 
Table 3.4 Extrinsic Reward from Positive Feedback Measurement

\section{Items}

1. When I received positive feedback, I earned better tips.

2. When I received positive feedback, I was rewarded with bonuses.

3. When I received positive feedback, I was rewarded with incentives.

4. When I received positive feedback, I was rewarded with paid time off.

5. When I received positive feedback, I was rewarded with benefits.

6. I was rewarded for receiving positive feedback.

7. Receiving positive feedback increased my opportunity to get a promotion.

Measurement of Job Satisfaction: The measurement of job satisfaction was adopted from the short version Minnesota Job Satisfaction Questionnaire (MSQ) that was developed by Weiss et al. (1967) and Bustamama, Tenga and Abdullahb (2014). In the short form MSQ job satisfaction scale, twenty items are used to measure an employee's satisfaction with their job. It is one of the most widely used scales in the related research. This scale was measured using a seven-point Likert-type scale varying from "strongly dissatisfied" (1) to "strongly satisfied" (7). The final score will determine the level of the employee's satisfaction with their job. The higher the score, the more satisfied the employee is. 
Items

1. The opportunity to work alone on the job.

2. Being able to keep busy all the time.

3. The opportunity to do different things from time to time.

4. The opportunity to be "somebody" in the community.

5. The way my boss interacts with his/her workers.

6. The competence of my supervisor in making decisions.

7. Being able to do things that don't go against my conscience.

8. The way my job provides for steady employment.

9. The opportunity to do things for other people.

10. The opportunity to tell people what to do.

11. The opportunity to do something that makes use of my abilities.

12. The way company policies are put into practice.

13. My pay and the amount of work I do.

14. The opportunity for advancement on this job.

15. The freedom to use my own judgment.

16. The opportunity to try my own methods of doing the job.

17. The working conditions.

18. The way my co-workers get along with each other.

19. The praise I get for doing a good job.

20. The feeling of accomplishment I get from the job. 
General Characteristics: This section was used to investigate demographic variables of the subjects. The questions covered basic information such as, gender, age, marital status, ethnicity, educational level, working experience, household income, etc.

\section{Sample and Data Collection}

The main objective of this research was to find out the influence of positive feedback and the rewards employees' perceived on their job satisfaction. According to previous research in the determination of sample size for SEM (Wolf, Harrington, Clark \& Miller, 2013; Bentler \& Chou, 1987; Bollen, 1989), an adequate sample size for this research would be 500 . The subjects were selected from the employees that work in the hospitality industry in greater Miami area. This research is quantitative in nature and the data was collected using convenience sampling by surveying employees with hospitality industry work experience. Five hundred questionnaires were administered in a two-month period. Of the 500 distributed, 442 were returned, with 339 being complete and usable for analysis.

\section{Method of Analysis}

In this study, SPSS 22 software was used to analyze the data collected.

Structural Equation Modeling was used to create a formula to model the relationship between perceived positive feedback from customers, perceived positive feedback summarized and delivered by managers, perceived intrinsic reward, perceived extrinsic reward and job satisfaction. 
Correlation Test was used to examine the relationships between each of the following variables: perceived positive feedback from customers, perceived positive feedback summarized and delivered by managers, intrinsic rewards, extrinsic reward, job satisfaction.

Regression analysis was used to create a regression formula among perceived positive feedback from customers, perceived positive feedback summarized and delivered by managers, intrinsic rewards, extrinsic reward and job satisfaction.

Reliability analysis was used to understand the reliability of each item by measuring the internal consistency of scales to make sure the questions are measuring the same concept (Tavakol \& Dennick, 2011).

T-test was used to analyze differences in: gender, position types and employment types of employees' perception toward perceived positive feedback from customers, perceived positive feedback summarized and delivered by managers, intrinsic rewards, extrinsic reward and job satisfaction.

ANOVA Test was used to investigate the relationships of different ethnicities, age group, educational levels, and other demographic variables on perceived positive feedback from customers, perceived positive feedback summarized and delivered by managers, intrinsic rewards, extrinsic reward and job satisfaction. 


\section{Summary}

This chapter illustrated the methodology used in the research. The data was

collected by questionnaire, and the subjects were people who have working experience in the hospitality industry in greater Miami area. SEM, correlations, ANOVAs, and t-tests were used to examine the instruments discussed in the chapter. The following chapter is the result of the data analysis. 


\section{Chapter IV}

\section{Result and Discussion}

The objective of this study was to understand the relationships among positive feedback from customers and managers, intrinsic rewards, extrinsic rewards and job satisfaction. The previous chapter described the methodology and the design of this research. In this chapter the analysis of the results of the questions being asked in the questionnaire will be presented.

The questionnaires were completed by subjects in the greater Miami area that have experience working in a hotel or a restaurant. A total of 500 questionnaires were distributed and 442 were returned. Of the returned questionnaires, 339 were valid surveys. Therefore, the response rate for the study was $67.8 \%$.

\section{Reliability Analysis}

Cronbach's alpha is a number between 0 and 1 that is used to measure the internal consistency of scales or measurement to make sure the questions are measuring the same concept (Tavakol \& Dennick, 2011). The acceptable range of Cronbach's alpha is provided by George and Mallery (2003) that when $\alpha$ is $>.9$, the internal consistency is Excellent, $\alpha>.8$ the consistency is good, $\alpha>.7$ is Acceptable, and when $\alpha$ is $<.5$ the consistency is Unacceptable.

In this research, the reliability test was conducted to make sure consistency of the questions asked in each measurement. According to the results displayed in table 4.1, intrinsic reward from positive feedback measurement and job satisfaction 
measurement had Cronbach's $\alpha$ values higher than 0.9 , positive feedback from customers measurement and extrinsic reward from positive feedback measurement had Cronbach's $\alpha$ values higher than 0.8 and positive feedback summarized \& delivered by managers measurement had an $\alpha$ value higher than 0.7 . Therefore, all the measurements in this research had $\alpha$ values higher than 0.7 , which suggested that the scales were reliable.

Table 4.1 Reliability analysis

\begin{tabular}{lccc}
\hline \multicolumn{1}{c}{ Measurement } & Items & Mean & Cronbach's $\alpha$ \\
\hline Customers positive feedback & 7 & 5.085 & .870 \\
Managers deliver positive feedback & 6 & 5.124 & .792 \\
Intrinsic reward & 7 & 6.358 & .938 \\
Extrinsic reward & 7 & 4.213 & .898 \\
Job satisfaction & 20 & 5.248 & .927 \\
\hline
\end{tabular}

\section{Correlation Analysis}

Correlation analyses aim to find out whether there is any linear correlation between the variables. The range of correlation coefficient is from -1 to 1 . According to the guide of the absolute value of r Evans (1996) suggested, the strength of linear correlations is interpreted that $r$ value is: .00-.19 "very weak", $.20-.39$ “weak", .40-.59 “moderate” ,.60-.79 “strong” , and .80-1.0 “very strong." In this research, Pearson's correlation was used to measure if there was a linear relationship between perceived positive feedback from customers, perceived positive 
feedback delivered by managers, intrinsic reward, extrinsic reward and job satisfaction as well as the strength of the linear relationship (Table 4.2).

Perceived positive feedback from customers and managers. According to the results in Table 4.2, perceived positive feedback from customers and perceived positive feedback delivered by managers had a strong and positive correlation $(\mathrm{r}=0.600 * *, \mathrm{p}<0.001)$

Perceived positive feedback and rewards. According to Table 4.2, perceived positive feedback from customers had a moderate positive relationship with intrinsic reward from positive feedback $\left(\mathrm{r}=0.444^{* *}, \mathrm{p}<0.001\right)$ and a positive moderate relationship with extrinsic rewards from positive feedback $\left(r=0.528^{* *}, \mathrm{p}<0.001\right)$. The results were significant, thus, hypothesis 1a: Positive feedback from guests is positively related to intrinsic rewards and hypothesis $1 \mathrm{~b}$ : Positive feedback from guests is positively related to extrinsic rewards were supported.

Perceived positive feedback summarized and delivered by managers was positively related to intrinsic reward from positive feedback with a moderate relationship $\left(\mathrm{r}=0.403^{* *}, \mathrm{p}<0.001\right)$ and it had a moderate positive relationship with extrinsic rewards from positive feedback $\left(\mathrm{r}=0.566^{* *}, \mathrm{p}<0.001\right)$. The results were significant, thus, hypothesis 2a: Positive feedback from guests summarized and delivered by a manager is positively related to intrinsic rewards and hypothesis $2 \mathrm{~b}$ : Positive feedback from guests summarized and delivered by a manager is positively related to extrinsic rewards were supported. 
Reward and Job Satisfaction. From the results displayed in Table 4.2, intrinsic rewards from positive feedback was positively related to job satisfaction $\left(\mathrm{r}=0.553^{* *}\right.$, $\mathrm{p}<0.001)$ and extrinsic rewards from positive feedback was also positively related to job satisfaction $\left(\mathrm{r}=0.529^{* *}, \mathrm{p}<0.001\right)$. Both rewards had a moderately positive relationship with job satisfaction and were significant. Therefore, hypothesis 3a: Received intrinsic rewards are positively related to job satisfaction and hypothesis $3 \mathrm{~b}$ : Received extrinsic rewards are positively related to job satisfaction were supported.

Positive Feedback and Job Satisfaction. According to the results in Table 4.2, perceived positive feedback from customers had a strong, positive correlation with job satisfaction $\left(\mathrm{r}=0.606^{* *}, \mathrm{p}<0.001\right)$. The result was significant, as a result, hypothesis 4 , positive feedback direct from customers is positively related to job satisfaction, was supported.

Perceived positive feedback summarized and delivered by managers also had a strong, positive correlation with job satisfaction $\left(\mathrm{r}=0.618^{* *}, \mathrm{p}<0.001\right)$. The result was also significant, therefore, hypothesis 5, positive feedback from guests, summarized and delivered by a manager is positively related to job satisfaction, was supported. 
Table 4.2 Correlation analysis

\begin{tabular}{|c|c|c|c|c|c|}
\hline & $\begin{array}{c}\text { Customers } \\
\text { positive feedback }\end{array}$ & $\begin{array}{l}\text { Managers deliver } \\
\text { positive feedback }\end{array}$ & Intrinsic reward & Extrinsic reward & Job satisfaction \\
\hline Customers positive feedback & 1 & $.600 * *$ & $.444 * *$ & $.528 * *$ & $.606^{* *}$ \\
\hline Managers deliver positive feedback & $.600 * *$ & 1 & $.403 * *$ & $.566^{* *}$ & $.618^{* *}$ \\
\hline Intrinsic reward & $.444 * *$ & $.403 * *$ & 1 & $.195 * *$ & $.553 * *$ \\
\hline Extrinsic reward & $.528 * *$ & $.566^{* *}$ & $.195 * *$ & 1 & $.529 * *$ \\
\hline Job satisfaction & $.606^{* *}$ & $.618^{* *}$ & $.553^{* *}$ & $.529 * *$ & 1 \\
\hline
\end{tabular}




\section{Regression Analysis}

The results of the correlation analyses suggested that there were relationships between the various constructs. Therefore, several multiple regression analyses were conducted to examine further predictions and explanations of the variable. The results of the multiple regression analyses are displayed in the following tables.

\section{Customers positive feedback and Managers deliver positive feedback on}

Intrinsic reward. The results of the multiple regression model are displayed in table 4.3, with $\Delta \mathrm{R}^{2}=0.222, \mathrm{~F}=49.227^{* *}$, which indicate that customers' positive feedback and managers delivery of positive feedback had a positive effect on intrinsic rewards perceived by the employee. The results suggest that employees with higher scores on the customers' positive feedback and managers delivery of positive feedback scales are expected to have higher intrinsic reward, after controlling for the other variables in the model.

Table 4.3 Regression analysis (Customers positive feedback, Managers deliver positive feedback \& Intrinsic reward)

\begin{tabular}{llllllll}
\hline Dependent Variable: & $\beta$ & $\mathrm{T}$ & $\mathrm{R}^{2}$ & $\Delta \mathrm{R}^{2}$ & $\mathrm{~F}$ & $\mathrm{VIF}$ \\
Intrinsic reward & & & & & &
\end{tabular}

$.227 \quad .222 \quad 49.227 * *$

$\begin{array}{llll}\text { Customers positive feedback } & .316^{* *} & 5.274 * * & 1.563 \\ \text { Managers deliver positive } & .213^{* *} & 3.558 * * & 1.563 \\ \text { feedback } & & & \end{array}$

$* * \mathrm{p}<0.001$ 


\section{Customers positive feedback and Managers deliver positive feedback on}

Extrinsic reward. The results of the multiple regression model are displayed in table 4.4, with $\Delta \mathrm{R}^{2}=0.372, \mathrm{~F}=101.269^{* *}$, which indicates that customers' positive feedback and managers delivery of positive feedback had a positive effect on the extrinsic rewards perceived by the employees. The results suggest that employees with higher scores on the customers' positive feedback and managers delivery of positive feedback scales are expected to have higher perception of extrinsic reward, after controlling for the other variables in the model.

Table 4.4 Regression analysis (Customers positive feedback, Managers deliver positive feedback \& Extrinsic reward)

\begin{tabular}{|c|c|c|c|c|c|c|}
\hline Dependent Variable: & $\beta$ & $\mathrm{T}$ & $\mathrm{R}^{2}$ & $\Delta \mathrm{R}^{2}$ & $\mathrm{~F}$ & VIF \\
\hline \multicolumn{7}{|l|}{ Extrinsic reward } \\
\hline & & & .376 & .372 & $101.269 * *$ & \\
\hline Customers positive feedback & $.294 * *$ & $5.465 * *$ & & & & 1.563 \\
\hline $\begin{array}{l}\text { Managers deliver positive } \\
\text { feedback }\end{array}$ & $.390 * *$ & $7.231 * *$ & & & & 1.563 \\
\hline
\end{tabular}

Intrinsic reward and Extrinsic reward on Job satisfaction. The results of the multiple regression model are displayed in table 4.5 , with $\Delta \mathrm{R}^{2}=0.487, \mathrm{~F}=161.301 * *$, which indicate that intrinsic reward and extrinsic reward had a positive effect on employees' job satisfaction. The results suggest that employees with higher scores on the perceived intrinsic reward and perceived extrinsic reward scales are expected to have higher job satisfaction, after the other variables in the model are controlled. 
Table 4.5 Regression analysis (Intrinsic reward, Extrinsic reward \& Job satisfaction)

\begin{tabular}{llllllll}
\hline $\begin{array}{l}\text { Dependent Variable: Job } \\
\text { satisfaction }\end{array}$ & $\beta$ & $\mathrm{T}$ & $\mathrm{R}^{2}$ & $\Delta \mathrm{R}^{2}$ & $\mathrm{~F}$ & $\mathrm{VIF}$ \\
\end{tabular}

$.490 \quad 487 \quad 161.301^{* *}$

$\begin{array}{llll}\text { Intrinsic reward } & .468 * * & 11.770 * * & 1.040 \\ \text { Extrinsic reward } & .437 * * & 11.011 * * & 1.040\end{array}$

$* * \mathrm{p}<0.001$

Customers positive feedback and Managers deliver positive feedback on Job

satisfaction. The results of the multiple regression are displayed in table 4.6, with $\Delta \mathrm{R}^{2}=0.465, \mathrm{~F}=148.110^{* *}$, which indicate that customers' positive feedback and managers delivery of positive feedback had positive effects on job satisfaction. The result suggest that employees with higher scores on the customers' positive feedback and managers delivery of positive feedback scales are expected to have higher job satisfaction, after controlling for the other variables in the model.

Table 4.6 Regression analysis (Customers positive feedback, Managers deliver positive feedback \& Job satisfaction)

\begin{tabular}{lcccccc}
\hline $\begin{array}{l}\text { Dependent Variable: Job } \\
\text { satisfaction }\end{array}$ & $\beta$ & $\mathrm{T}$ & $\mathrm{R}^{2}$ & $\Delta \mathrm{R}^{2}$ & $\mathrm{~F}$ & $\mathrm{VIF}$ \\
\hline & & & & & & \\
& & & .469 & .465 & $148.110^{* *}$ & \\
Customers positive feedback & $.368^{* *}$ & $7.407 * *$ & & & & 1.563 \\
$\begin{array}{l}\text { Managers deliver positive } \\
\text { feedback }\end{array}$ & $.397 * *$ & $7.982^{* *}$ & & & & 1.563 \\
\hline$* * \mathrm{p}<0.001$ & & & & & & \\
\end{tabular}




\section{Customers positive feedback, Managers deliver positive feedback, Intrinsic}

reward and Extrinsic reward on Job satisfaction. The results of the multiple regression model are displayed in table 4.7 , with $\Delta \mathrm{R}^{2}=0.562, \mathrm{~F}=109.390^{* *}$, which indicate that customers' positive feedback, managers delivery of positive feedback, intrinsic reward, and extrinsic reward had a positive effect on the job satisfaction employees perceived. The results suggest that employees with higher scores on all the four scales are expected to have higher job satisfaction, after controlling for the other variables in the model.

Table 4.7 (Customers positive feedback, Managers deliver positive feedback, Intrinsic reward, Extrinsic \& Job satisfaction)

\begin{tabular}{lcccccc}
\hline $\begin{array}{l}\text { Dependent Variable: Job } \\
\text { satisfaction }\end{array}$ & $\beta$ & $\mathrm{T}$ & $\mathrm{R}^{2}$ & $\Delta \mathrm{R}^{2}$ & $\mathrm{~F}$ & $\mathrm{VIF}$ \\
\hline & & & & & \\
& & & .567 & .562 & $109.390^{* *}$ & \\
Customers positive feedback & $.200^{* *}$ & $4.064^{* *}$ & & & & 1.873 \\
Managers deliver positive & $.241^{* *}$ & $4.849^{* *}$ & & & 1.903 \\
feedback & & & & & 1.317 \\
Intrinsic reward & $.323^{* *}$ & $7.826^{* *}$ & & & 1.632 \\
Extrinsic reward & $.224^{* *}$ & $4.860^{* *}$ & & & \\
\hline
\end{tabular}

$* * \mathrm{p}<0.001$

\section{Structural Equation Modeling}

SPSS AMOS 21 was used to conduct SEM, which was used to examine the causal relationships between the five variables in this research. The results of goodness of fit of this research model were $\chi^{2}=6.098, \mathrm{df}=1, \mathrm{p}<.05, \chi^{2} / \mathrm{df}=6.098$, $\mathrm{GFI}=.993, \mathrm{IFI}=0.993, \mathrm{TLI}=0.925, \mathrm{CFI}=0.992, \mathrm{RMSEA}=.123$. Among the 
results, RMSEA indicated a poor fit with the data and $\chi^{2} / \mathrm{df}$ also indicated that there might be some underlying problem within the model. However, GFI, IFI, TLI and CFI were in an acceptable range. The structural model is displayed in Figure 4.1 and the standardized path coefficient $(\beta)$ is shown in table 4.8 .

Table 4.8 Structural equation modeling

\begin{tabular}{llll}
\hline \multicolumn{2}{c}{ Path } & & $\beta$ \\
\hline Customers positive feedback & $\rightarrow$ & Managers deliver \\
positive feedback & $.600^{* *}$ \\
Customers positive feedback & $\rightarrow$ & Intrinsic reward & $.316^{* *}$ \\
Customers positive feedback & $\rightarrow$ & Extrinsic reward & $.294^{* *}$ \\
Managers deliver positive & $\rightarrow$ & Intrinsic reward \\
feedback & & & $.213^{* *}$ \\
Managers deliver positive & $\rightarrow$ & Extrinsic reward \\
feedback & & Job satisfaction & $.390^{* *}$ \\
Intrinsic reward & $\rightarrow$ & Job satisfaction \\
Extrinsic reward & $\rightarrow$ & Job satisfaction & $.321^{* *}$ \\
Customers positive feedback & & Job satisfaction & $.222^{* *}$ \\
Managers deliver positive & & & $.199^{* *}$ \\
feedback & & & $.239^{* *}$ \\
\hline$* * p<0.001$ & & & \\
\hline
\end{tabular}




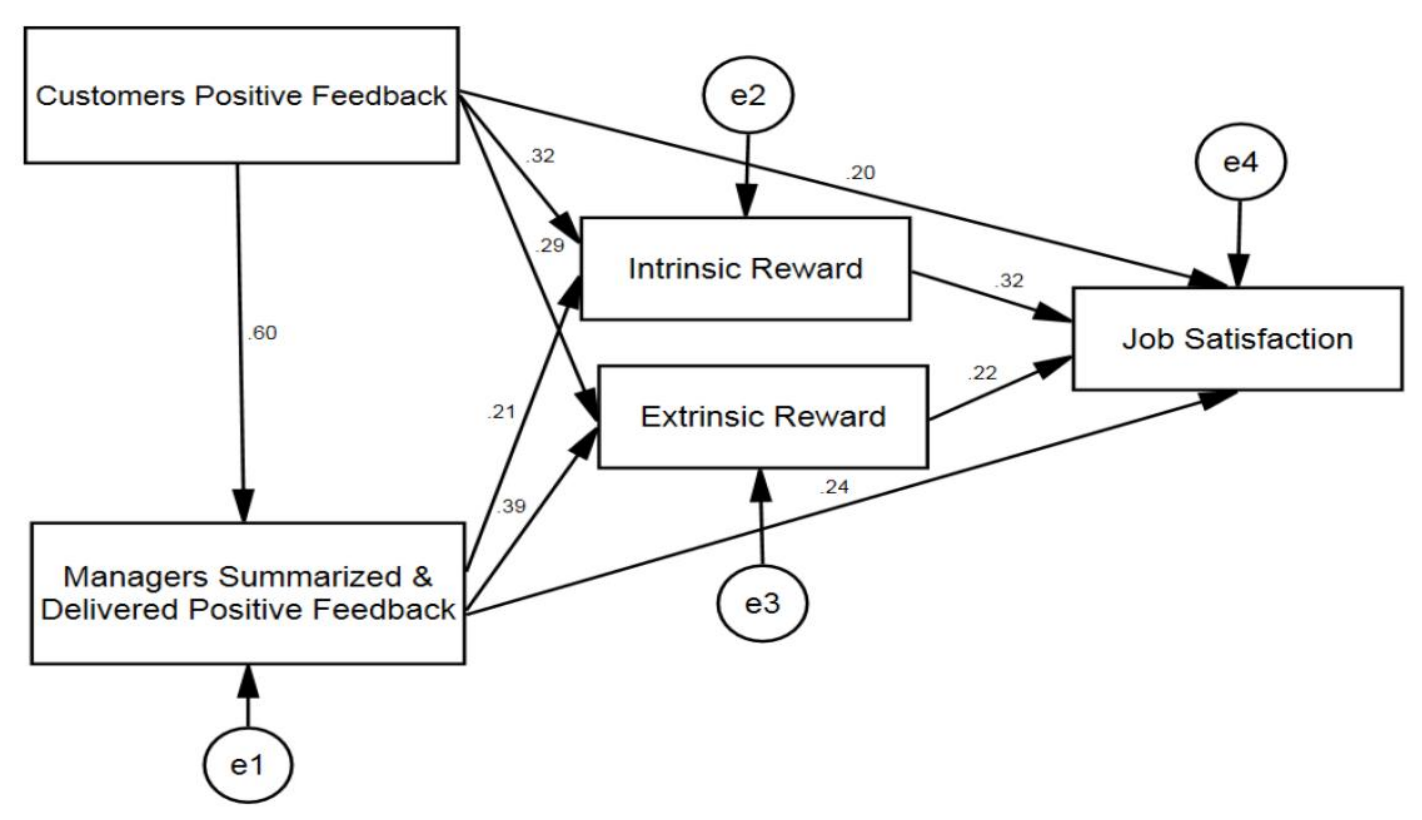

Figure 4.1 Structural equation modeling

\section{Analysis of Demographic Data}

The results of the demographic analyses are display in table 4.9 that among the 339 valid samples, there were $30.4 \%$ male participants and $69.6 \%$ female participants. The majority age group was 20- 29 years old, and the median was age of 24 . Most of the respondents were single, never married. Hispanic and Asian composed the major respondents. Most of the respondents obtained college degree and above.

As for the working experiences, most of the participants, have 1 to 2 years of experiences. The majority of the respondents have experiences working in hotels. 65.2 $\%$ of the respondents have experiences obtaining a full-time job, which are more than the ones that have part-time job experience in the hospitality industry. Most of the respondents have experience working in upper upscale-midscale properties that followed by luxury properties, then followed economy properties. The major income group of respondents were composed by less than $\$ 20,000$ and $\$ 20,000$ to 39,999 . 
Table 4.9 Demographic distribution

\begin{tabular}{|c|c|c|c|}
\hline & & $\mathrm{n}$ & $\%$ \\
\hline \multirow{2}{*}{ Gender } & Male & 103 & 30.4 \\
\hline & Female & 236 & 69.6 \\
\hline \multirow{5}{*}{ Age } & 19 and below & 5 & 1.5 \\
\hline & $20-29$ & 292 & 86.1 \\
\hline & 30- 39 & 26 & 7.7 \\
\hline & 40- 49 & 12 & 3.2 \\
\hline & 50 and above & 5 & 1.2 \\
\hline \multirow{3}{*}{ Marital status } & Single, never married & 309 & 91.2 \\
\hline & Married & 27 & 8 \\
\hline & Separated, divorced or widowed & 3 & 0.9 \\
\hline \multirow{6}{*}{ Ethnicity } & African-American & 24 & 7.1 \\
\hline & Caucasian & 32 & 9.4 \\
\hline & Native American & 2 & 0.6 \\
\hline & Asian & 151 & 44.5 \\
\hline & Hispanic & 115 & 33.9 \\
\hline & Other & 15 & 4.4 \\
\hline \multirow{5}{*}{ Education } & Some school & 6 & 1.8 \\
\hline & High school graduate or equivalent & 14 & 4.1 \\
\hline & some college includes 2 -year degree & 58 & 17.1 \\
\hline & 4-year college degree & 156 & 46 \\
\hline & graduate or professional degree & 105 & 31 \\
\hline
\end{tabular}




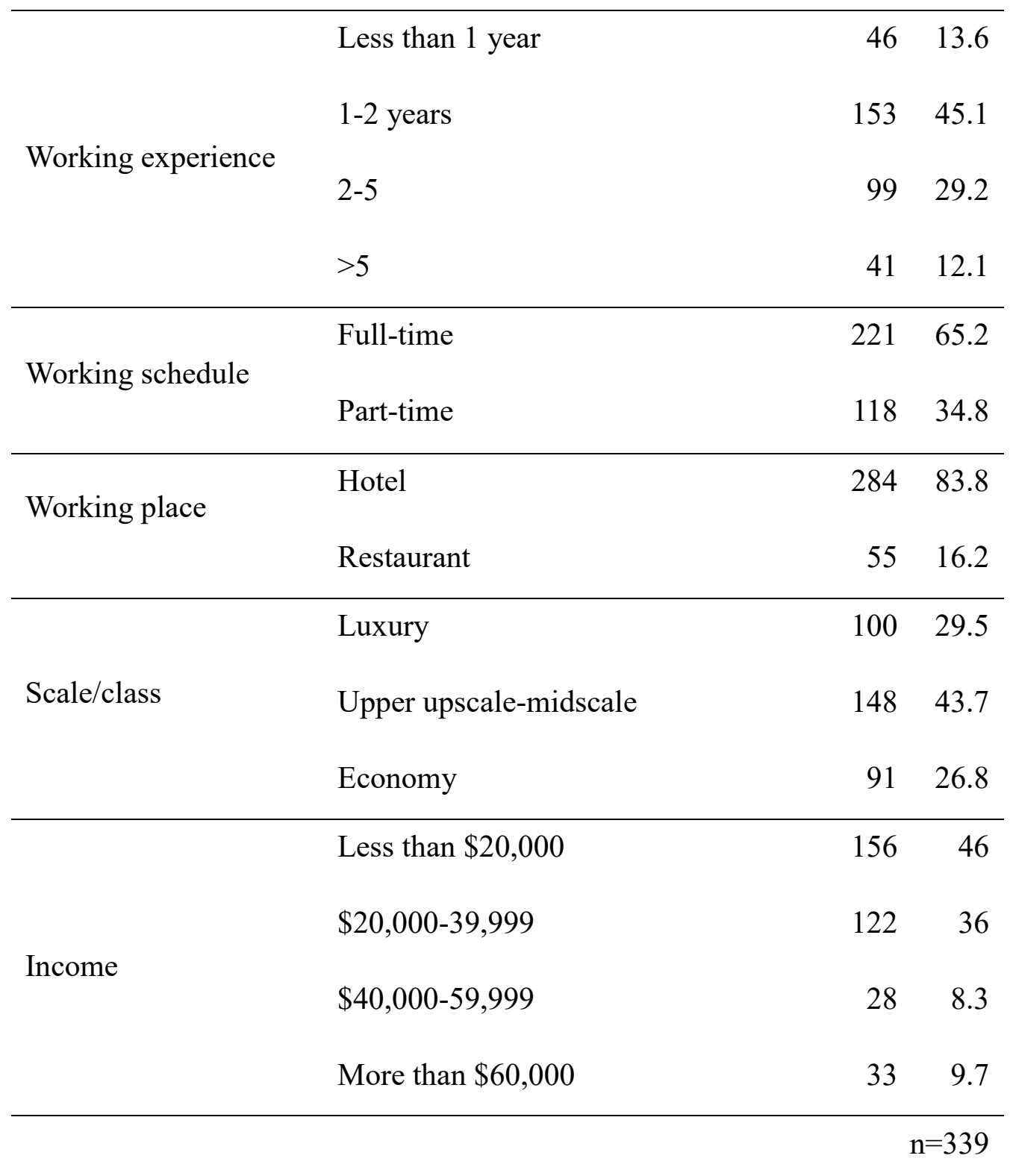

\section{Differences in Gender Groups}

T-tests were used to analyze the differences between gender groups. According to table 4.10 , the results of perceived customers positive feedback were $t=1.767$ and $\mathrm{p}=0.320$, which suggests that there was no significant difference between male participants $(M=36.816, S D=8.233)$ and female participants $(M=35.064, S D=8.465)$.

The results of the perception of managers delivery of positive feedback from customers were $\mathrm{t}=1.521$ and $\mathrm{p}=0.036^{*}$, which suggests that there was a significant 
difference between male participants $(\mathrm{M}=31.990, \mathrm{SD}=8.068)$ and female participants $(\mathrm{M}=30.119, \mathrm{SD}=10.694)$.

For intrinsic reward received from positive feedback, the $t$-test result was $t=-$ 0.921 and $p=0.175$, which suggested that there was no difference between male participants $(\mathrm{M}=44.058, \mathrm{SD}=5.076)$ and female participants $(\mathrm{M}=44.703, \mathrm{SD}=6.263)$.

For the results of extrinsic reward received from positive feedback, the t-test results were $\mathrm{t}=2.561$ and $\mathrm{p}=0.036^{*}$, which suggests that there was a significant difference between male participants $(\mathrm{M}=31.942, \mathrm{SD}=10.465)$ and female participants $(\mathrm{M}=28.424, \mathrm{SD}=12.106)$.

As for the job satisfaction, the results were $t=0.692, p=0.241$, which suggested that there was no significant difference between male participants $(\mathrm{M}=106.058, \mathrm{SD}=$ 17.192) and female participants $((M=104.483, S D=20.313)$. 
Table 4.10 T-test (Gender group)

\begin{tabular}{|c|c|c|c|c|c|c|}
\hline & Gender & $\mathrm{n}$ & $\mathrm{t}$ & $\mathrm{p}$ & Mean & SD \\
\hline \multirow{2}{*}{ Customers positive feedback } & Male & 103 & \multirow{2}{*}{1.767} & \multirow{2}{*}{.320} & 36.816 & 8.233 \\
\hline & Female & 236 & & & 35.064 & 8.465 \\
\hline \multirow{2}{*}{$\begin{array}{l}\text { Managers deliver positive } \\
\text { feedback }\end{array}$} & Male & 103 & \multirow{2}{*}{1.521} & \multirow{2}{*}{$.036^{*}$} & 31.990 & 8.068 \\
\hline & Female & 236 & & & 30.199 & 10.694 \\
\hline \multirow[b]{2}{*}{ Intrinsic reward } & Male & 103 & \multirow{2}{*}{-.921} & \multirow{2}{*}{.175} & 44.058 & 5.076 \\
\hline & Female & 236 & & & 44.703 & 6.263 \\
\hline \multirow{2}{*}{ Extrinsic reward } & Male & 103 & \multirow{2}{*}{2.561} & \multirow{2}{*}{$.036^{*}$} & 31.942 & 10.465 \\
\hline & Female & 236 & & & 28.424 & 12.106 \\
\hline \multirow{2}{*}{ Job satisfaction } & Male & 103 & \multirow{2}{*}{.692} & \multirow{2}{*}{.241} & 106.058 & 17.192 \\
\hline & Female & 236 & & & 104.483 & 20.131 \\
\hline
\end{tabular}

$* \mathrm{p}<0.05$.

\section{Differences in Working Place Groups}

According to the t-test analyses, the results of the differences between working place groups are shown in table 4.11. The results of perceived customers positive feedback were $\mathrm{t}=0.713$ and $\mathrm{p}=0.504$, which suggested that there was no significant difference between participants that have experiences working in hotels $(M=35.739$, $\mathrm{SD}=8.441)$ and participants with experiences working in restaurants $(\mathrm{M}=34.854$, $\mathrm{SD}=8.359)$.

For the results of differences in perception of perceived managers summarized and delivery of customers positive feedback between working place groups, the t-test results were $\mathrm{t}=0.529$ and $\mathrm{p}=0.881$. The results were not significant; thus, there was no 
significant difference between participants that have experiences working in hotels $(\mathrm{M}=30.870, \mathrm{SD}=10.173)$ and participants with experiences working in restaurants $(\mathrm{M}=30.091, \mathrm{SD}=10.173)$

The t-test results for intrinsic reward received from positive feedback, were $\mathrm{t}=1.517$ and $\mathrm{p}=0.455$, which suggests that there was no significant difference between participants with experiences working in hotels $(\mathrm{M}=44.722, \mathrm{SD}=5.773)$ and participants with experiences working in restaurants $(\mathrm{M}=43.400, \mathrm{SD}=6.618)$.

The results for extrinsic reward received from positive feedback were $t=-0.815$ and $p=0.934$, which suggests that there was no significant difference between participants with experiences working in hotels $(\mathrm{M}=29.264, \mathrm{SD}=11.750)$ and participants with experiences working in restaurants $(\mathrm{M}=30.672, \mathrm{SD}=11.654)$.

As for the job satisfaction, the results were $\mathrm{t}=1.361, \mathrm{p}=0.948$, which suggests that there was no significant difference between participants with experiences working in hotels $(\mathrm{M}=105.588, \mathrm{SD}=18.950)$ and participants with experiences working in restaurants $((\mathrm{M}=101.727, \mathrm{SD}=20.751)$. 
Table 4.11 T-test (Working place group)

\begin{tabular}{|c|c|c|c|c|c|c|}
\hline & $\begin{array}{c}\text { Place } \\
\text { working }\end{array}$ & $\mathrm{n}$ & $\mathrm{t}$ & $\mathrm{p}$ & Mean & $\mathrm{SD}$ \\
\hline \multirow[b]{2}{*}{ Customers positive feedback } & Hotel & 248 & \multirow[b]{2}{*}{.713} & \multirow[b]{2}{*}{.504} & 35.739 & 8.441 \\
\hline & Restaurant & 55 & & & 34.854 & 8.359 \\
\hline \multirow{2}{*}{$\begin{array}{l}\text { Managers deliver positive } \\
\text { feedback }\end{array}$} & Hotel & 248 & \multirow{2}{*}{.529} & \multirow{2}{*}{.881} & 30.870 & 10.173 \\
\hline & Restaurant & 55 & & & 30.091 & 9.052 \\
\hline \multirow[b]{2}{*}{ Intrinsic reward } & Hotel & 248 & \multirow{2}{*}{1.517} & \multirow{2}{*}{.455} & 44.722 & 5.773 \\
\hline & Restaurant & 55 & & & 43.400 & 6.618 \\
\hline \multirow[b]{2}{*}{ Extrinsic reward } & Hotel & 248 & \multirow[b]{2}{*}{-.815} & \multirow[b]{2}{*}{.934} & 29.264 & 11.750 \\
\hline & Restaurant & 55 & & & 30.672 & 11.654 \\
\hline \multirow{2}{*}{ Job satisfaction } & Hotel & 248 & \multirow{2}{*}{1.361} & \multirow{2}{*}{.948} & 105.588 & 18.950 \\
\hline & Restaurant & 55 & & & 101.727 & 20.751 \\
\hline
\end{tabular}

\section{Differences in Working Schedule Groups}

The t-test results for the differences between working schedule groups are shown in table 4.12. The $\mathrm{t}$-test results of perceived customers positive feedback were $\mathrm{t}=0.310$ and $p=0.024^{*}$, which suggests that there was a statistically significant difference between participants that have full-time positions $(\mathrm{M}=35.606, \mathrm{SD}=8.796)$ and participants have part-time positions $(\mathrm{M}=35.576, \mathrm{SD}=7.708)$.

For the results of differences in perception of perceived managers summarized and delivery of customers positive feedback between working schedule groups, the ttest results were $\mathrm{t}=0.111$ and $\mathrm{p}=0.678$. The results were not significant; thus, there was no significant difference between participants that have full-time positions 
$(\mathrm{M}=30.787, \mathrm{SD}=9.382)$ and participants have part-time positions $(\mathrm{M}=30.661$, $\mathrm{SD}=11.086)$.

The results for intrinsic reward received from positive feedback were $t=-0.617$ and $p=0.154$, which suggests that there was no significant difference between participants that have full-time positions $(\mathrm{M}=44.362, \mathrm{SD}=6.423)$ and participants have part-time positions ( $\mathrm{M}=44.780, \mathrm{SD}=4.880)$.

The results for extrinsic reward received from positive feedback were $t=-2.347$ and $p=0.707$, which suggests that there was no difference between participants that have full-time positions $(\mathrm{M}=28.407, \mathrm{SD}=11.614)$ and participants have part-time positions $(\mathrm{M}=31.525, \mathrm{SD}=11.722)$.

As for the job satisfaction, the results were $t=-0.955, p=0.260$, which suggested that there was no significant difference between participants that have full-time positions $(\mathrm{M}=104.230, \mathrm{SD}=20.230)$ and participants have part-time positions $(\mathrm{M}=106.330, \mathrm{SD}=17.343)$. 
Table 4.12 T-test (Working schedule group)

\begin{tabular}{|c|c|c|c|c|c|c|}
\hline & $\begin{array}{l}\text { Working } \\
\text { schedule }\end{array}$ & $\mathrm{n}$ & $\mathrm{t}$ & $\mathrm{p}$ & Mean & SD \\
\hline & Full-time & 221 & \multirow{2}{*}{.031} & & 35.606 & 8.796 \\
\hline Customers positive feedback & Part-time & 118 & & $024 *$ & 35.576 & 7.708 \\
\hline Managers deliver positive & Full-time & 221 & \multirow{2}{*}{.111} & \multirow{2}{*}{.678} & 30.787 & 9.382 \\
\hline feedback & Part-time & 118 & & & 30.661 & 11.086 \\
\hline & Full-time & 221 & \multirow{2}{*}{-.617} & \multirow{2}{*}{.154} & 44.362 & 6.423 \\
\hline Intrinsic reward & Part-time & 118 & & & 44.780 & 4.880 \\
\hline \multirow{3}{*}{ Extrinsic reward } & Full-time & 221 & \multirow[t]{2}{*}{-2.347} & \multirow[t]{2}{*}{.707} & 28.407 & 11.614 \\
\hline & Part-time & 118 & & & 31.525 & 11.722 \\
\hline & Full-time & 221 & \multirow{2}{*}{-9.55} & \multirow{2}{*}{.260} & 104.230 & 20.230 \\
\hline Job satisfaction & Part-time & 118 & & & 106.330 & 17.343 \\
\hline
\end{tabular}

$* \mathrm{p}<0.05$.

\section{Differences in Dimension in Ethnicity Groups}

The test of homogeneity was conducted to and the results were displayed in

Table 4.13. Customers positive feedback $(p=0.168)$, managers deliver positive feedback $(p=0.103)$, intrinsic reward $(p=0.425)$ and extrinsic reward $(p=0.116)$ had significance levels larger than 0.05 , which meant that the homogeneity of variance was not significant. Therefore, ANOVA was conducted to find out whether there were any differences among the respondents from different ethnic groups. The results of ANOVA were shown in table 4.14. However, the significance level of job satisfaction $(p=0.003 *)$ was significant $(p=0.003)$; thus, ANOVA was invalid. 
Table 4.13 Homogeneity test (Ethnicity group)

\begin{tabular}{lcccc}
\hline & Levene Statistic & df1 & df2 & Sig. \\
\hline Customers positive feedback & 1.692 & 3 & 335 & .168 \\
Managers deliver positive feedback & 2.075 & 3 & 335 & .103 \\
Intrinsic reward & .933 & 3 & 335 & .425 \\
Extrinsic reward & 1.702 & 3 & 335 & .116 \\
Job satisfaction & 4.628 & 3 & 335 & $.003 * *$ \\
\hline$* * \mathrm{p}<0.01$ & & & &
\end{tabular}

For perceived customers' positive feedback, the ANOVA results were $F=0.908$, $\mathrm{p}=0.438$, which suggests that there was no significant differences among participants in different ethnic groups.

For perceived managers deliver positive feedback from customers, the results of ANOVA were $F=0.385, p=0.764$, which suggests that there was no significant difference among participants in different ethnic groups.

For intrinsic rewards received from positive feedback, the ANOVA results were $\mathrm{F}=0.860, \mathrm{p}=0.462$, which suggests that there was no significant differences among participants in different ethnic groups.

The ANOVA results for extrinsic rewards received from positive feedback were $\mathrm{F}=2.630, \mathrm{p}=0.050$, which suggests that there were statistically significant differences among participants in different ethnic groups. According to Tukey's HSD test, Asian employees perceived more extrinsic rewards from positive feedback than the ones in the category others. 
Table 4.14 ANOVA (Ethnicity group)

\begin{tabular}{|c|c|c|c|c|c|c|c|}
\hline & Ethnic & $\mathrm{n}$ & $\mathrm{F}$ & $\mathrm{P}$ & Mean & $\mathrm{SD}$ & Post-hoc \\
\hline \multirow{4}{*}{$\begin{array}{c}\text { Customers } \\
\text { positive } \\
\text { feedback }\end{array}$} & a. Caucasian & 32 & \multirow{4}{*}{.908} & \multirow{4}{*}{.438} & 37.281 & 10.313 & \\
\hline & b. Asian & 151 & & & 35.880 & 8.330 & \\
\hline & c. Hicnanic & 115 & & & 34713 & 8307 & \\
\hline & d. Others & 41 & & & 35.707 & 8.186 & \\
\hline \multirow{4}{*}{$\begin{array}{c}\text { Managers } \\
\text { deliver } \\
\text { positive } \\
\text { feedback }\end{array}$} & a. Caucasian & 32 & \multirow{4}{*}{.385} & \multirow{4}{*}{.462} & 31.813 & 8.867 & \\
\hline & b. Asian & 151 & & & 31.133 & 9.688 & \\
\hline & c. Hispanic & 115 & & & 30.096 & 11.273 & \\
\hline & d. Others & 41 & & & 30.293 & 8.216 & \\
\hline \multirow{4}{*}{$\begin{array}{c}\text { Intrinsic } \\
\text { reward }\end{array}$} & a. Caucasian & 32 & \multirow{4}{*}{.860} & \multirow{4}{*}{.959} & 44.250 & 5.452 & \\
\hline & b. Asian & 151 & & & 44.007 & 6.899 & \\
\hline & c. Hispanic & 115 & & & 44.930 & 5.399 & \\
\hline & d. Others & 41 & & & 45.366 & 6.073 & \\
\hline \multirow{4}{*}{$\begin{array}{c}\text { Extrinsic } \\
\text { reward }\end{array}$} & a. Caucasian & 32 & \multirow{4}{*}{2,630} & \multirow{4}{*}{$.050 *$} & 29.313 & 12.890 & \multirow{4}{*}{$a>d$} \\
\hline & b. Asian & 151 & & & 30.78 & 11.369 & \\
\hline & c. Hispanic & 115 & & & 29.504 & 12.102 & \\
\hline & d. Others & 41 & & & 25.449 & 11.034 & \\
\hline
\end{tabular}

\section{Differences in Dimension in Education Groups}

The test of homogeneity was conducted and the results were displayed in Table 4.15. Customers positive feedback $(p=0.281)$, managers deliver positive feedback $(p=0.294)$, intrinsic reward $(p=0.716)$, extrinsic reward $(p=0.723)$ and job satisfaction $(p=0.326)$ had significance level $>0.05$, which meant that the homogeneity of variance 
were not significant. Therefore, ANOVA was conducted to find out whether there were any differences among the respondents obtained different education level. The results of ANOVA were shown in table 4.16

Table 4.15 Homogeneity test (Education group)

\begin{tabular}{lcccc}
\hline & Levene Statistic & df1 & df2 & Sig. \\
\hline Customers positive feedback & 1.280 & 3 & 335 & .281 \\
Managers deliver positive feedback & 1.242 & 3 & 335 & .294 \\
Intrinsic reward & .451 & 3 & 335 & .716 \\
Extrinsic reward & .442 & 3 & 335 & .723 \\
Job satisfaction & 1.157 & 3 & 335 & .326 \\
\end{tabular}

For perceived customers' positive feedback, the ANOVA results were $F=0.475$, $\mathrm{p}=0.700$, which suggests that there was no significant difference among participants in different education groups.

The ANOVA results for perceived managers deliver positive feedback from customers were $\mathrm{F}=0.606, \mathrm{p}=0.612$, which suggests that there was no significant difference among participants in different education groups.

For intrinsic rewards received from positive feedback, the results of ANOVA were $F=2.352, p=0.072$, which suggests that there was no significant difference among participants in different education groups. 
For perceived extrinsic rewards received from positive feedback, the ANOVA results were $\mathrm{F}=1.483, \mathrm{p}=0.219$, which suggests that there was no significant difference among participants in different education groups.

As for the perception of job satisfaction, the ANOVA results were $F=0.999$, $\mathrm{p}=0.393$, which suggests that there was no significant difference among participants in different education groups. 
Table 4.16 ANOVA (Education group)

\begin{tabular}{|c|c|c|c|c|c|c|c|}
\hline & Education level & $\mathrm{n}$ & $\mathrm{F}$ & $\mathrm{P}$ & Mean & SD & $\begin{array}{l}\text { Post- } \\
\text { hoc }\end{array}$ \\
\hline \multirow{4}{*}{$\begin{array}{c}\text { Customers } \\
\text { positive } \\
\text { feedback }\end{array}$} & a. High school \& below & 20 & \multirow{4}{*}{.475} & \multirow{4}{*}{.700} & 35.650 & 10.313 & \\
\hline & b. Some college ( 2 year) & 58 & & & 35.052 & 8.330 & \\
\hline & c. College (4 Year) & 156 & & & 35.256 & 8.397 & \\
\hline & d. Graduate/professional & 105 & & & 36.391 & 8.186 & \\
\hline \multirow{4}{*}{$\begin{array}{c}\text { Managers } \\
\text { deliver } \\
\text { positive } \\
\text { feedback }\end{array}$} & a. High school \& below & 20 & \multirow{4}{*}{.606} & \multirow{4}{*}{.612} & 30.900 & 8.867 & \\
\hline & b. Some college (2 year) & 58 & & & 30.000 & 9.688 & \\
\hline & c. College (4 Year) & 156 & & & 30.289 & 11.273 & \\
\hline & d. Graduate/professional & 105 & & & 31.800 & 8.216 & \\
\hline \multirow{4}{*}{$\begin{array}{l}\text { Intrinsic } \\
\text { reward }\end{array}$} & a. High school \& below & 20 & \multirow{4}{*}{2.352} & \multirow{4}{*}{.072} & 41.400 & 5.452 & \\
\hline & b. Some college (2 year) & 58 & & & 44.138 & 6.899 & \\
\hline & c. College (4 Year) & 156 & & & 45.039 & 5399 & \\
\hline & d. Graduate/professional & 105 & & & 44.514 & 6.073 & \\
\hline \multirow{4}{*}{$\begin{array}{c}\text { Extrinsic } \\
\text { reward }\end{array}$} & a. High school \& below & 20 & \multirow{4}{*}{1.483} & \multirow{4}{*}{.219} & 31.550 & 12.890 & \\
\hline & b. Some college (2 year) & 58 & & & 28.793 & 11.369 & \\
\hline & c. College (4 Year) & 156 & & & 28.359 & 12.102 & \\
\hline & d. Graduate/professional & 105 & & & 31.171 & 11.034 & \\
\hline \multirow{4}{*}{$\begin{array}{c}\text { Job } \\
\text { satisfaction }\end{array}$} & a. High school \& below & 20 & \multirow{4}{*}{.999} & \multirow{4}{*}{.393} & 103.250 & 25.062 & \\
\hline & b. Some college ( 2 year) & 58 & & & 102.897 & 19.217 & \\
\hline & c. College (4 Year) & 156 & & & 104.192 & 19.396 & \\
\hline & d. Graduate/professional & 105 & & & 107.571 & 17.853 & \\
\hline
\end{tabular}




\section{Differences in Dimension in Working Experience Groups}

The results of homogeneity test were displayed in Table 4.17. Customers positive feedback $(\mathrm{p}=0.838)$, managers deliver positive feedback $(\mathrm{p}=0.101)$, intrinsic reward $(p=0.765)$, extrinsic reward $(p=0.496)$ and job satisfaction $(p=0.478)$ all had significance levels $>0.05$, which meant that the homogeneity of variance were not significant. Therefore, ANOVA was conducted to indicate whether there were any differences among the respondents obtained different years of working experiences. The results of ANOVA were shown in table 4.18

Table 4.17 Homogeneity test (experience)

\begin{tabular}{lcccc}
\hline & Levene Statistic & df1 & df2 & Sig. \\
\hline Customers positive feedback & .282 & 3 & 335 & .838 \\
Managers deliver positive feedback & 2.093 & 3 & 335 & .101 \\
Intrinsic reward & .383 & 3 & 335 & .765 \\
Extrinsic reward & .797 & 3 & 335 & .496 \\
Job satisfaction & .830 & 3 & 335 & .478 \\
\hline
\end{tabular}

The ANOVA results of perceived customers' positive feedback were $\mathrm{F}=0.364$, $p=0.779$, which suggests that there was no significant difference among participants in different working experience groups.

For the results of differences in perception of perceived managers summarized and delivery of positive feedback from customers, the ANOVA results were $\mathrm{F}=0.388$, $\mathrm{p}=0.762$, which suggests that there was no significant difference among participants in different working experience group. 
For perceived intrinsic rewards received from positive feedback, the ANOVA results were $F=0.352, p=0.787$, which suggests that there was no significant difference among participants in different working experience groups.

The result for perceived extrinsic rewards received from positive feedback were $\mathrm{F}=1.079, \mathrm{p}=0358$, which suggests that there was no significant difference among participants in different working experience groups on.

As for the job satisfaction, the results were $F=0.015, p=0.997$, which suggests that there was no significant difference among participants in different working experience groups. 
Table 4.18 ANOVA (Experience)

\begin{tabular}{|c|c|c|c|c|c|c|c|c|}
\hline & & $\begin{array}{l}\text { Years of } \\
\text { xperience }\end{array}$ & $\mathrm{n}$ & $\mathrm{F}$ & $\mathrm{P}$ & Mean & SD & $\begin{array}{l}\text { Post } \\
\text {-hoc }\end{array}$ \\
\hline \multirow{4}{*}{$\begin{array}{c}\text { Customers } \\
\text { positive } \\
\text { feedback }\end{array}$} & a. & $<1$ year & 46 & \multirow{4}{*}{.364} & \multirow{4}{*}{.779} & 35.652 & 8.266 & \\
\hline & b. & 1-2 years & 153 & & & 36.078 & 8.107 & \\
\hline & c. & $2-5$ years & 99 & & & 35.080 & 8.726 & \\
\hline & d. & $>5$ years & 41 & & & 34.976 & 9.177 & \\
\hline \multirow{4}{*}{$\begin{array}{l}\text { Managers } \\
\text { deliver } \\
\text { positive } \\
\text { feedback }\end{array}$} & a. & $<1$ year & 46 & \multirow{4}{*}{.388} & \multirow{4}{*}{.762} & 30.457 & 7.831 & \\
\hline & b. & 1-2 years & 153 & & & 30.294 & 9.039 & \\
\hline & c. & $2-5$ years & 99 & & & 31.647 & 12.413 & \\
\hline & d. & $>5$ years & 41 & & & 30.561 & 9.146 & \\
\hline \multirow{4}{*}{$\begin{array}{l}\text { Intrinsic } \\
\text { reward }\end{array}$} & a. & $<1$ year & 46 & \multirow{4}{*}{0.352} & \multirow{4}{*}{.0787} & 43.870 & 5.500 & \\
\hline & b. & $1-2$ years & 153 & & & 44.712 & 5.995 & \\
\hline & c. & $2-5$ years & 99 & & & 44.303 & 6.351 & \\
\hline & d. & $>5$ years & 41 & & & 44.951 & 5.152 & \\
\hline \multirow{4}{*}{$\begin{array}{c}\text { Extrinsic } \\
\text { reward }\end{array}$} & a. & $<1$ year & 46 & \multirow{4}{*}{1.079} & \multirow{4}{*}{.358} & 31.217 & 11.197 & \\
\hline & b. & 1-2 years & 153 & & & 30.130 & 11.312 & \\
\hline & c. & $2-5$ years & 99 & & & 28.485 & 12.157 & \\
\hline & d. & $>5$ years & 41 & & & 27.610 & 12.728 & \\
\hline \multirow{4}{*}{$\begin{array}{c}\text { Job } \\
\text { satisfaction }\end{array}$} & a. & $<1$ year & 46 & \multirow{4}{*}{.015} & \multirow{4}{*}{.997} & 105.435 & 16.706 & \\
\hline & b. & $1-2$ years & 153 & & & 104.834 & 19.566 & \\
\hline & c. & $2-5$ years & 99 & & & 104.889 & 20.707 & \\
\hline & d. & $>5$ years & 41 & & & 104.195 & 17.870 & \\
\hline
\end{tabular}




\section{Differences in Dimension in Scale/class of Working Place Groups}

The test of homogeneity was conducted and the results were displayed in Table 4.19. Customers positive feedback ( $\mathrm{p}=0.066)$, managers deliver positive feedback $(p=0.101)$, intrinsic reward $(p=0.319)$, extrinsic reward $(p=0.504)$ and job satisfaction $(p=0.683)$ had significance level $>0.05$, which meant that the homogeneity of variance were not significant. Therefore, ANOVA was conducted to find out whether there were any differences among the respondents worked in different scales/classes properties. The results of ANOVA were shown in table 4.20

Table 4.19 Homogeneity test (Scale/class)

\begin{tabular}{lcccc}
\hline & Levene Statistic & df1 & df2 & Sig. \\
\hline Customers positive feedback & 2.745 & 2 & 336 & .066 \\
Managers deliver positive feedback & 2.310 & 2 & 336 & .101 \\
Intrinsic reward & 1.147 & 2 & 336 & .319 \\
Extrinsic reward & .687 & 2 & 336 & .504 \\
Job satisfaction & .381 & 2 & 336 & .683 \\
\hline
\end{tabular}

The ANOVA results for perceived customers' positive feedback were $F=3.873$, $\mathrm{p}=0.022^{*}$, which suggests that there were statistically significant differences among participants work in different scales/classes properties. According to Tukey's HSD test, the employees with working experiences in luxury properties perceived more customers' positive feedback than those who had experience working in upper upscale to midscale properties. 
For perceived managers deliver positive feedback from customers, the ANOVA results were $F=1.795, p=0.168$, which suggests that there was no significant difference among participants work in different scales/classes properties.

For perceived intrinsic rewards received from positive feedback, the ANOVA results were $\mathrm{F}=0.908, \mathrm{p}=0.404^{*}$, which suggests that there was no significant difference among participants with working experiences in different scales/classes properties.

For perceived extrinsic rewards received from positive feedback, the ANOVA results were $\mathrm{F}=0.508, \mathrm{p}=0.602$, which suggests that there was no significant difference among participants with working experiences in different scales/classes properties.

As for the job satisfaction, the ANOVA results were $\mathrm{F}=1.945, \mathrm{p}=0.145$, which suggests that there was no significant difference among participants with working experiences in different scales/classes properties. 
Table 4.20 ANOVA (Scale/class)

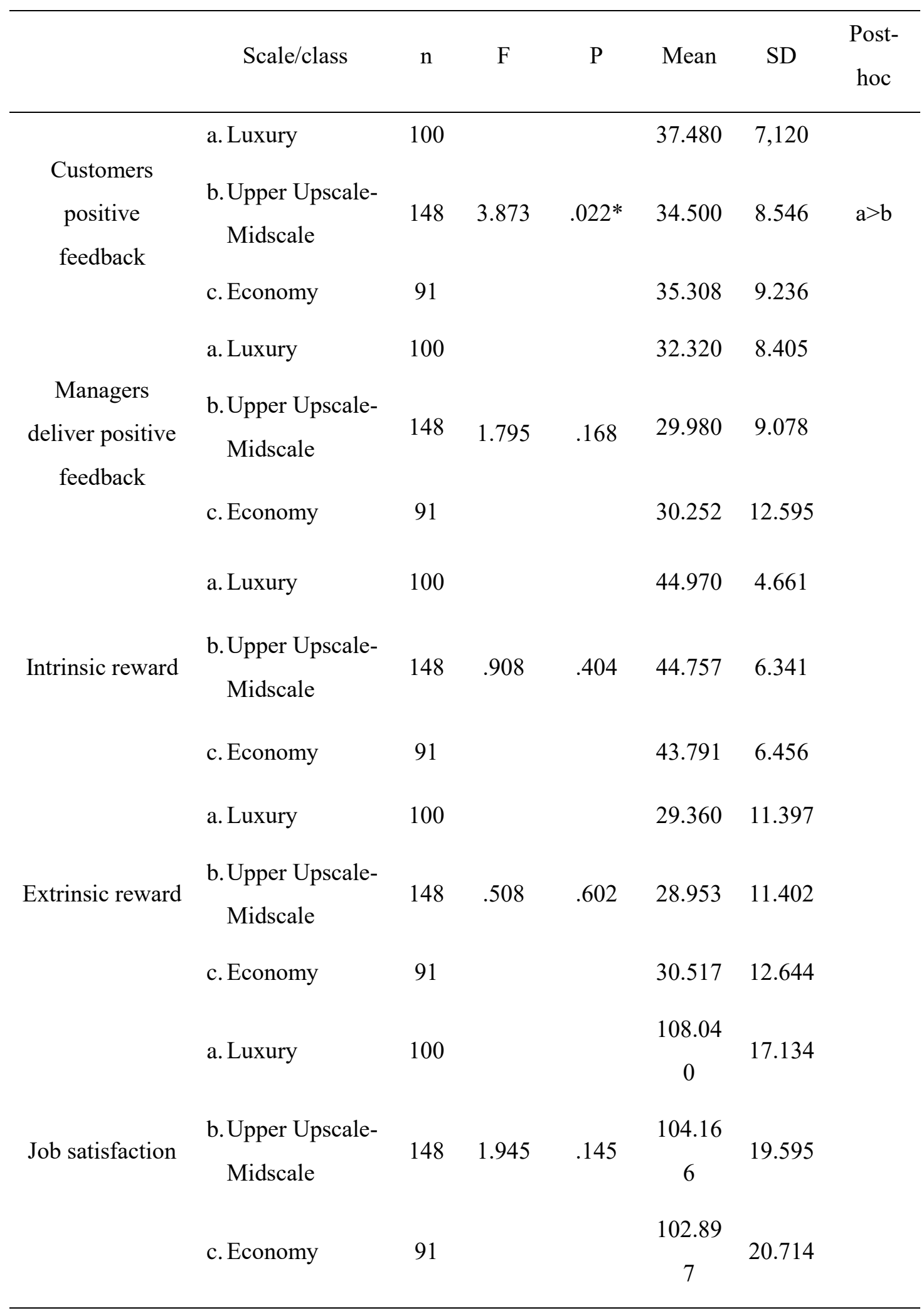

$*_{\mathrm{p}}<0.05$ 


\section{Differences in Income Groups}

The test of homogeneity was conducted to find out the whether the group variances are equal, and the results were displayed in Table 4.21. Customers positive feedback $(p=0.518)$, managers deliver positive feedback $(p=0.901)$, extrinsic reward $(p=0.816)$ and job satisfaction $(p=0.298)$ had significance level $>0.05$, which meant that the homogeneity of variances were not significant. Therefore, ANOVA was conducted to find out whether there were any differences among the respondents with different income. As for intrinsic reward $(\mathrm{p}=0.024 *)$, the homogeneity of variance was significant; thus, ANOVA was invalid. The results of ANOVA were shown in table 4.22.

Table 4.21 Homogeneity test (Income)

\begin{tabular}{lcccc}
\hline & Levene Statistic & df1 & df2 & Sig. \\
\hline Customers positive feedback & .659 & 2 & 336 & .518 \\
Managers deliver positive feedback & .105 & 2 & 336 & .901 \\
Intrinsic reward & 3.762 & 2 & 336 & $.024^{*}$ \\
Extrinsic reward & .203 & 2 & 336 & .816 \\
Job satisfaction & 1.214 & 2 & 336 & .298 \\
\hline${ }^{*}<0.05$ & & & &
\end{tabular}

The ANOVA results for perceived customers' positive feedback were $F=4.052$, $\mathrm{p}=0.018^{*}$, which suggests that there were statistically significant differences among participants with different income level. According to Tukey's HSD test, the employees with income from $\$ 20,000-39,999$ perceived more customers' positive feedback than those who earned less than $\$ 20,000$. 
For the results of differences in perception of perceived managers summarized and delivery of positive feedback from customers, the ANOVA results were $\mathrm{F}=6.381$, $\mathrm{p}=0.002 * *$, which suggests that there were statistically significant differences among participants with different income level. Furthermore, the employees with income from $\$ 20,000-39,999$ had a higher perception of perceived managers deliver positive feedback from customers than those who earned less than $\$ 20,000$.

For perceived extrinsic rewards received from positive feedback, the ANOVA results were $\mathrm{F}=3.876, \mathrm{p}=0.022^{*}$, which suggests that there were statistically significant differences among participants with different income level. Also, the employees with income from $\$ 20,000-39,999$ perceived more extrinsic rewards received from positive feedback than those who earned more than $\$ 40,000$.

About the job satisfaction, the ANOVA results were $\mathrm{F}=4.359, \mathrm{p}=0.014^{*}$, which suggests that there were statistically significant differences among participants with different income level. The employees with income from \$20,000-39,999 had higher job satisfaction than those who earned less than $\$ 20,000$. 
Table 4.22 ANOVA (Income)

\begin{tabular}{|c|c|c|c|c|c|c|c|}
\hline & Income & $\mathrm{n}$ & $\mathrm{F}$ & $\mathrm{P}$ & Mean & $\mathrm{SD}$ & $\begin{array}{l}\text { Post- } \\
\text { hoc }\end{array}$ \\
\hline \multirow{3}{*}{$\begin{array}{l}\text { Customers } \\
\text { positive } \\
\text { feedback }\end{array}$} & a. $<\$ 20,000$ & 156 & & & 34.763 & 8.506 & \multirow{3}{*}{$\mathrm{b}>\mathrm{a}$} \\
\hline & $\begin{array}{c}\text { b. } \$ 20,000- \\
39,999\end{array}$ & 122 & 4.052 & $.018^{*}$ & 37.303 & 7.885 & \\
\hline & c. $>\$ 40,000$ & 61 & & & 34.311 & 8.823 & \\
\hline \multirow{3}{*}{$\begin{array}{c}\text { Managers } \\
\text { deliver } \\
\text { positive } \\
\text { feedback }\end{array}$} & a. $<\$ 20,000$ & 156 & & & 28.840 & 9.202 & \multirow{3}{*}{$\mathrm{b}>\mathrm{a}$} \\
\hline & $\begin{array}{l}\text { b. } \$ 20,000- \\
39,999\end{array}$ & 122 & 6.381 & $.002 * *$ & 33.082 & 10.760 & \\
\hline & c. $>\$ 40,000$ & 61 & & & 30.934 & 9.466 & \\
\hline \multirow{3}{*}{$\begin{array}{c}\text { Extrinsic } \\
\text { reward }\end{array}$} & a. $<\$ 20,000$ & 156 & & & 29.160 & 12.033 & \multirow{3}{*}{$b>c$} \\
\hline & $\begin{array}{c}\text { b. } \$ 20,000- \\
39,999\end{array}$ & 122 & 3.876 & $.022 *$ & 31.443 & 11.330 & \\
\hline & c. $>\$ 40,000$ & 61 & & & 26.443 & 11.162 & \\
\hline \multirow{3}{*}{$\begin{array}{c}\text { Job } \\
\text { satisfaction }\end{array}$} & a. $<\$ 20,000$ & 156 & & & 102.051 & 19.803 & \multirow{3}{*}{$\mathrm{b}>\mathrm{a}$} \\
\hline & $\begin{array}{c}\text { b. } \$ 20,000- \\
39,999\end{array}$ & 122 & 4.359 & $.014^{*}$ & 108.853 & 17.217 & \\
\hline & c. $>\$ 40,000$ & 61 & & & 104.623 & 20.708 & \\
\hline
\end{tabular}




\section{Discussion}

Based on the research objectives and hypotheses, the analyses were conducted and results are shown in the previous chapter. The following section will discuss these results.

From the results of the analyses of customers' positive feedback and managers summarized and delivery of positive feedback, it shown that not all positive feedback from customers were delivered to the employees because the R-value of correlation was less than 1 . However, the delivery of positive feedback does impact the employees' perceptions of the rewards received and job satisfaction, which will be discussed in the following section.

Perceived positive feedback and rewards. H1a: Positive feedback from guests is positively related to intrinsic rewards, $\mathrm{H} 1 \mathrm{~b}$ : Positive feedback from guests is positively related to extrinsic rewards, H2a: Positive feedback from guests summarized and delivered by a manager is positively related to intrinsic rewards, and $\mathrm{H} 2 \mathrm{~b}$ : Positive feedback from guests summarized and delivered by a manager is positively related to extrinsic rewards were supported by the results of correlation analyses. Additionally, the findings from the regression analyses and SEM suggest that positive feedback from customers had higher positive effects to the intrinsic reward employees perceived compared to the effects from perceived positive feedback summarized and delivered by managers. However, perceived positive feedback summarized and delivered by managers had a higher positive impact on perceived extrinsic reward compared to perceived positive feedback from customers. 
Reward and Job Satisfaction. H3a: Received intrinsic rewards are positively related to job satisfaction and $\mathrm{H} 3 \mathrm{~b}$ : Received extrinsic rewards are positively related to job satisfaction were supported by the results from the correlation analyses Furthermore, the findings from regression analyses and SEM indicated that intrinsic reward had higher positive effects to job satisfaction compared to extrinsic reward to job satisfaction.

Positive Feedback and Job Satisfaction. From the correlation analyses, H4: positive feedback directly from customers is positively related to job satisfaction and H5: positive feedback from guests summarized and delivered by managers is positively related to job satisfaction were supported and in accordance with the expectations. The findings from the regression analyses and SEM both indicated that perceived positive feedback from guests summarized and delivered by managers had greater effects on employees' job satisfaction compared to positive feedback directly from customers.

Differences in Gender Groups. The findings of the t-test showed that there were a statistically differences perceptions of the positive feedback delivered by managers and extrinsic rewards they received between male and female respondents. However, the differences between other dimensions were not significant. The reason that cause the differences can be done by future research to find out the factors influence employees the perception of managers' positive feedback.

Differences in Work Place and Schedule Groups. The results from t-test were not significant, which suggested there was no difference between employees 
working in hotels or restaurants and obtained full-time job or part-time job. The reason for having the results might be the uneven numbers of the respondents working in same groups of the categories.

Differences in Ethnic Groups. According to the results from ANOVA, there was no significant difference among the different ethnic groups on their perception to the five dimensions. Most the respondents were Asians and Hispanics, which is lack of the varieties of participants from other ethnic groups. Therefore, this research failed to investigate whether different cultural have influences on the perception of positive feedback, rewards received and job satisfaction.

Differences in Income Groups. According to the results from ANOVA, there were significant differences among the different income groups on their perception to the five dimensions. The employees with income from $\$ 20,000-39,999$ had higher perceived positive feedback from customers, managers delivered positive feedback, and job satisfaction than those who earned less than $\$ 20,000$.

Differences in Scale/class of Working Place Groups. Even the result of ANOVA suggested that there was a significant difference in perceived positive feedback from customer among the respondents had experience working in different scale/class of properties. The respondents worked in luxury property perceived more positive feedback from customer than those who worked in upper upscale to midscale properties. However, there was not significant difference for the positive feedback delivered by managers, intrinsic reward, extrinsic reward and job satisfaction. 
Working Experience Groups, Age Group, Marital Status and Education

Group. The results for the groups above were not significant. This research is failed to examine these aspects because the distribution of the respondents was to concentrated in same categories. Therefore, the results might have biases based on the focused subjects.

\section{Summary}

This chapter presented the results of the analyses in the research. Detailed results and interpretations of correlation, structural equation modeling, multiple regression, ttest, and ANOVA were explained and discussed in each section. 


\section{Chapter V}

\section{Conclusion and recommendation}

In this chapter, conclusions and limitations of this research will be illustrated based on the results and discussion, as well as recommendations for future research based on the limitations of this research.

\section{Conclusion}

The purpose of this research was to examine whether customers' positive feedback, managers' delivery of the positive feedback, intrinsic and extrinsic reward they received from the feedback influenced employees job satisfaction in the hospitality industry. The reason this research is engaging in investigation of the relationship between positive feedback and job satisfaction is because positive job satisfaction is found to have a significant relationship with employees' performance, organization commitment and turnover intention (Judge, Thoresen, Bono, \& Patton, 2001; Barrow,1990; Carsten \& Spector, 1987).

The overall result suggested that the hospitality employees receive positive feedback either direct from customers or delivered by managers would have both intrinsic reward and extrinsic reward, which supported the theories from Harackiewicz (1979). However, perceived positive feedback summarized and delivered by managers had a higher positive impact on perceived extrinsic reward compared to perceived positive feedback from customers. Another way to explain perceived positive feedback summarized and delivered by managers had a higher 
positive impact on perceived extrinsic reward is that the contents of extrinsic rewards are provided by the hospitality firms. Therefore, if the managers did not recognize the positive feedback, there will not be any reward.

The result of intrinsic rewards and extrinsic are positively related to job satisfaction from the correlation analyses met the expectation and was accord to previous research (Pratheepkanth, 2011). Additional findings were that intrinsic reward had higher positive effects to job satisfaction compared to extrinsic reward to job satisfaction, which is consistence with previous research that suggested intrinsic reward had higher effects on job satisfaction (Nyame-Mireku, 2012; Chuang, Yin \& Dellmann-Jenkins, 2009).

There are some interesting findings from this research that the hospitality employees had higher job satisfaction when they receive positive feedback from customers, especially for managers summarized and the delivery of positive customer feedback, which had greater impacts on employees' job satisfaction than direct positive customer feedback. In other words, it is important for managers to deliver customers' positive feedback to the employees, which correspond with the suggestion from previous research, managers have great influence on job satisfaction (Moynihan \& Pandley, 2007). Therefore, it is suggested that a hospitality organization should encourage the leaders to deliver the positive feedback from customers to the employees, while accompanied with rewards to enhance the positive feedback to increase employees' job satisfaction. 
Another interesting finding from this research is that direct positive customer feedback had higher influences to employees' perceived intrinsic reward than positive feedback delivered by managers. Additionally, the finding of this research also suggested that intrinsic reward had a greater effect on job satisfaction. Therefore, the hospitality firms could also encourage the customers to leave a positive feedback to the hard-working employees to motivate or as a reference to reward them. Not only for managers to deliver the positive feedback to employees, the human resources department should also put the positive feedback in the employees' records as a foundation for future evaluation. To adopt the idea of paying attention to the importance of positive feedback is influenced by the organizational culture. However, it is important to utilize the low-cost method to increase the job satisfaction and take the benefits to increase chances of earning higher profit for the organization, while providing the employees a better working environment.

Additional important finding of this research is the different perceptions of positive feedback among diverse income groups. The interpretation for the results is that for the income group $\$ 20,000-39,999$, the range of average income front-line employees earned in the hospitality (Glassdoor, 2018) had a higher perception of positive feedback and job satisfaction than those who earned below the average income of front-line employees in the hospitality industry. Therefore, the results indicated that positive feedback had more effects on those who earned about the average income of the hospitality frontline employees compared to subjects who earned less than the average. And for the respondents that had income more than the 
average, it had less impact from the extrinsic reward they received in comparison to the average income group. Such finding implicated Maslow's Hierarchy of Need Theory that workers earn lower income are struggling with lower level of needs, and they are more likely to be motivated by the basic need in the workplace, money, in other words extrinsic rewards is more effective to them. However, because the measurements in this research are too general, we were not able to present the factors that determined the perceptions. Therefore, it needs deeper investigations to find out the best measures to motivate, encourage and reward the hospitality employees in different income groups. As to increase their job satisfaction in the most efficient way.

To conclude the findings from this research, the hospitality organizations should be aware of how positive customer feedback drives employees job satisfaction. Therefore, the practical implications for the industry are: firstly, the organization need to encourage customers to complement the employees directly and/or leave them positive feedback; however, it is for organization level and managerial level to encourage customers, instead of asking employees to tell the customers to fill out the survey and give the minimum required numbers of survey the need to received. Secondly, managers should actively collect positive feedback from all the feedback collecting channel of the organization and the human resource department could make use of the positive feedback collected as a basis for future evaluation. Thirdly, managers need to summarize customer positive feedback and deliver it to the employees. There are various ways for managers to deliver the message such as post 
in the company bulletin board, send the positive feedback from customer to the employee's email or praised the one who received the positive feedback during meeting. Finally, the results suggested that the implications above about positive feedback should be applied on the employees within the average income range in order to be more effective.

\section{Limitations}

This research is not free from limitations; overall results of demographic analyses were not significant because this study was based on a sample with similar backgrounds. Firstly, the data collecting method was convenience sampling that respondents were those who are easier to reach out, which happened to the group with similar backgrounds. Therefore, the subjects should be more evenly distributed, especially for age, marital status and tenure. Second, the respondents were the hospitality employees with working experience in restaurant or hotel. However, there are a lot more job types in the industry, such as cruises, airlines, resorts, theme parks and other areas of the hospitality industry that might have influences on employees' different perception of the positive feedback should be considered to avoid biases. Third, the questionnaires were conducted by subjects with working experience in greater Miami area, however, the hospitality workers are all over the world, and different culture from both employee and customers, salaries and type of target guests will influence the results. Also, there are more factors that could have impacts on the results, such as perceived fairness, service climate, reward responsiveness, etc. were not tested in this research. Lastly, the measurements were testing general perceptions 
of positive feedback and rewards; thus, there were unable to indicate the specific measures that influence, motivate or matter the most to the employees.

\section{Recommendation}

This study is focusing on the impact of positive feedback to the hospitality workers, which is relatively rare to other studies in the industry. The recommendations for future research can address the limitation of this research. Firstly, future study should investigate the employees from different cultures and their perception of positive feedback. Additionally, the cultural differences of customers should also be investigated, because in some culture people are more willing to complement others, but some do not. Secondly, future studies could target diverse subjects from other areas of job occupations in the hospitality industry to have a more accurate result and could also examine whether there are any differences on their perceptions between workers of different job types. Thirdly, future studies could investigate on different forms of positive feedback (OTA reviews, Social Media, written satisfaction forms, verbal, etc.) and the effectiveness of each kind of positive feedback on employees' perceptions and satisfaction. Fourthly, this research is a cross-sectional study, but if using a longitudinal research to compare subjects' perception before and after emphasized the delivery of positive feedback to generate more implications. Last but not the least, this research was focusing on individuals' perceptions toward the positive feedback they received. However, it will be interesting to investigate the impacts of putting the positive customer feedback into property levels, as the operating of a property in the hospitality are not only 
depending on frontline employees, but also the efforts of back-office employees.

Therefore, the delivery of positive customer positive feedback to the entire property

might be an opportunity for future studies to contribute to the hospitality industry and human resource management.

\section{Summary}

In this chapter, the conclusion of the entire research was discussed. Limitations of this study and recommendations for future studies were also presented for those who are interested in suppressing the extent and findings of this research. 


\section{References}

Ajmal, A., Bashir, M., Abrar, M., Khan, M. M., \& Saqib, S. (2012). Intrinsic motivation and employee attitudes. Review of Public Personnel Administration, 32(4), 382-406.

Allen, R. S., \& Kilmann, R. H. (2001). The role of the reward system for a total quality management based strategy. Journal of Organizational Change Management 14 (2), 110-131.

Armstrong, M. (2006). A Handbook of Human resource Management Practice, Tenth Edition, Kogan Page Publishing, London, p. 264

Arnett, D.B., Laverie, D.A. and McLane, C. (2002), "Using job satisfaction and pride as internal-marketing tools", Cornell Hotel and Restaurant Administration, Vol. 43 No. 2, pp. 87-96.

Aziri, B. (2011). Job satisfaction: A literature review. Management Research and Practice, 3(4), 77-86.

Barbosa-McCoy, V. (2016). Hotel managers' motivational strategies for enhancing employee performance (Doctoral dissertation, Walden University).

Barrow, C. W. (1990). Employee turnover: Implications for hotel managers. FIU Hospitality Review, 8(1), 24-31.

Belschak, F. D., \& Den Hartog, D. N. (2009). Consequences of positive and negative feedback: The impact on emotions and extra-role behaviors. Applied Psychology an International Review, 58(2), 274-303.

Bentler P. M., Chou C. H. (1987). Practical issues in structural modeling. Sociological Methods \& Research, 16, 78-117.

Birmingham, P., \& Wilkinson, D. (2003). Using research instruments: A guide for researchers. Routledge, p 8-12.

Bollen K. A. (1989). Structural equations with latent variables. New York, NY: John Wiley. 
Bouckenooghe, D., Raja, U., \& Butt, A. N. (2013). Combined effects of positive and negative affectivity and job satisfaction on job performance and turnover intentions. The Journal of Psychology, 147(2), 105-123.

Bulgarella, C. C. (2005) 'Employee Satisfaction and Customer Satisfaction: Is there a relationship?', A White Paper from Guide Star Research.

Bustamam, F. L., Teng, S. S., \& Abdullah, F. Z. (2014). Reward management and job satisfaction among frontline employees in hotel industry in malaysia. Procedia Social and Behavioral Sciences, 144, 392-402.

Butler, R. (1987). Task-involving and ego-involving properties of evaluation: Effects of different feedback conditions on motivational perceptions, interests, and performance. Journal of Educational Psychology, 79, 474-482.

Cadotte, E., \& Turgeon, N. (1988). Key factors in guest satisfaction. The Cornell Hotel and Restaurant Administration Quarterly, 28(4), 44.

Carsten. J. M. \& Spector, P. E. (1987). Unemployment, Job satisfaction and employee turnover: A meta- Analytic Test of the Murchinsky Model. Journal of Applied Psychology, 8, 374-381.

Chapman, G. and White, P. (2011), The 5 Languages of Appreciation in the Workplace: Empowering Organizations by Encouraging People, Northfield Press, Chicago, IL.

Chiang, C., \& Jang, S. (2008). An expectancy theory model for hotel employee motivation. International Journal of Hospitality Management, 27(2), 313-322.

Chuang, N., Yin, D., \& Dellmann-Jenkins, M. (2009). Intrinsic and extrinsic factors impacting casino hotel chefs' job satisfaction. International Journal of Contemporary Hospitality Management, 21(3), 323-340.

Cialdini, R.B. (2007). Influence. The psychology of persuasion, Collins Business.

Conroy, M. A., Sutherland, K. S., Snyder, A., Al-Hendawi, M., \& Vo, A. (2009). Creating a positive classroom atmosphere: Teachers' use of effective praise and feedback. Beyond Behavior, 18, 18-26.

Evans, J. D. (1996). Straightforward statistics for the behavioral sciences. Pacific Grove, CA: Brooks/Cole Publishing. 
Fredrickson B. (2004) The broaden-and-build theory of positive emotions.

Philosophical Transactions of the Royal Society London B Biological Sciences $359,1367-1377$.

Fredrickson, B. L. (2009). Positivity. New York: Three Rivers Press.

Gelade, G. A., and S. Young. 2005. Test of a service profit chain model in the retail banking sector. Journal of Occupational and Organizational Psychology 78:1-22.

George, D., \& Mallery, P. (2003). SPSS for Windows step by step: A simple guide and reference. 11.0 update (4th ed.). Boston: Allyn \& Bacon.

George, J.M. and Jones, G.R. (2008). Understanding and Managing Organizational behavior, Fifth Edition, Pearson/Prentice Hall, New Jersey.

Glassdoor. (2018, May). Front Desk Agent Salaries. Retrieved from https://www.glassdoor.com/Salaries/front-desk-agent-salary-SRCH_KO0,16.htm

Glinska-Newes, A., \& Stankiewicz, M. J. (2012). Positive organizational potential as a fundamental factor of corporate competitiveness. Competition Forum, 10(1), 321.

Harackiewicz, J. (1979). The effects of reward contingency and performance feedback on intrinsic motivation. Journal of Personality and Social Psychology, $37,1352-1363$.

Hattie, J. \& Timperley, H. (2007). The power of feedback. Review of Educational Research, 77(1), 81-112.

Herzberg, F., Mausner, B., \& Snyderman, B. B. (1959). The Motivation to Work (2nd ed.). New York: John Wiley \& Sons.

Heskett, J. L., Sasser, W. E., \& Schlesinger, L. A. (1997). The service profit chain. New York, NY: The Free Press

Hon, A.H.Y., Chan, W.W.H. and Lu, L. (2013), “Overcoming work-related stress and promoting employee creativity in hotel industry: the role of task feedback from supervisor”, International Journal of Hospitality Management, Vol. 33, pp. 416424.

Hoppock, R. (1935). Job Satisfaction, Harper and Brothers, New York. 
Idemobi, I., Ngige, C. D. \& Ofili. P. N., Relationship Between Organization Reward System and Workers Attitude to Work. Journal of Business and Economic Development. Vol. 2, No. 4, 2017, pp. 247-254.

Intrinsic. (2013). In Pocket Oxford English Dictionary (11 $1^{\text {th }}$ ed.). Oxford, UK: Oxford: Oxford University Press.

Ittner, C.D. \& Larcker, D.F. (2003). Coming Up Short on Nonfinancial Performance Measurement. Harvard Business Review 81, 88-95.

Jaworski, B.J. \& Kohli, A. K. (1991). Supervisory feedback: Alternative types and their impact on salespeople's performance and satisfaction. Journal of Marketing Research, 28(2), 190-201.

Johanson, M. M., \& Woods, R. H. (2008). Recognizing the emotional element in service excellence. Cornell Hospitality Quarterly, 49(3), 310-316.

Judge, T. A., Thoresen, C. J., Bono, J. E., \& Patton, G. K. (2001). The job satisfaction-job performance relationship: A qualitative and quantitative review. Psychological Bulletin, 127, 376-407.

Kalleberg, A. L. (1977). Work values and job rewards: a theory of job satisfaction. American Sociological Review 42: 124-143.

Kara, D., Uysal, M., \& Magnini, V. P. (2012). Gender differences on job satisfaction of the five-star hotel employees. International Journal of Contemporary Hospitality Management, 24(7), 1047-1065.

Karatepe, O. M., et al, 2006. The effects of selected individual characteristics on frontline employee performance and job satisfaction. Tourism Management, 27, pp.547-560

Katz, R. and Van Maanan, J. (1977). The Loci of Work Satisfaction: Job Interaction, and Policy. Human Relations, 30: 469-86.

Kim, W. G., \& Park, S. A. (2016). Social media review rating versus traditional customer satisfaction. International Journal of Contemporary Hospitality Management, 29(2), 784-802. 
Kipfelsberger, P., Herhausen, D. \& Bruch, H. (2016). How and when customer feedback influences organizational health. Journal of Managerial Psychology, 31(2), 624-640.

Kitterlin, M., Moll, L. (2012). Organizational Behavior: A Skills-Based Approach, p. 157.

Kluger, A. N., \& DeNisi, A. (1996). The effects of feedback interventions on performance: A historical review, a meta-analysis, and a preliminary feedback intervention theory.

Koka, A., \& Hein, V. (2005). The Effect of Perceived Teacher Feedback on Intrinsic Motivation in Physical Education. International Journal of Sport Psychology, 36(2), 91-106.

Kreps, D. M. (1997). Intrinsic motivation and extrinsic incentives. The American Economic Review, 87(2), 359-364.

Kulhavy, R. W. (1977). Feedback in written instruction. Review of Educational Research, 47(2), 211-232.

Locke, E. A. (1969). What is job satisfaction? Organizational Behavior and Human Performance 4: 309-336.

London, M., Larsen, H. H. and Thisted, L. N. (1999). Relationships between Feedback and Self-Development. Group and Organization Management 24(1): $5-27$.

Luthans, F., \& Kreitner, R. (1975). Organizational Behavior Modification, Glenview, IL: Scott Foresman.

Maslow, A. H. (1943). A Theory of Human Motivation. Psychological Review, 50(4), 370-96.

McLeod, S. A. (2014). Maslow's Hierarchy of Needs. Retrieved from www.simplypsychology.org/maslow.html

Morgan, B. (2015). Happy Employees Equals Happy Customers. Forbes. Retrieved from http://www.forbes.com/sites/blakemorgan/2015/03/04/happy-employeesequals-happy-customers/2/.

Mossbarger M., Eddington J. 2003. Methods for Motivating Employee. 
Mottaz, C. J., (1985). The Relative Importance of Intrinsic and Extrinsic Rewards as Determinants of Work Satisfaction. The Sociological Quarterly, 26(3), 365-385.

Mouratidis, A., Vansteenkiste, M., Lens, W. and Sideridis, G. 2008. The motivating role of positive feedback in sport and physical education: Evidence for a motivational model. Journal of Sport \& Exercise Psychology, 30: 240-268.

Moynihan, D.P. \& Pandey, S.K. (2007). The Role of Organizations in Fostering Public Service Motivation. Public Administration Review 67, 40-53.

Mulder, R. H., Ellinger, A. D. (2013). Perceptions of quality of feedback in organizations. Characteristics, determinants, outcomes of feedback, and possibilities for improvement: Introduction to a special issue. European Journal of Training and Development, 37, 4-23.

Nasr, L., Burton, J., Gruber, T., \& Kitshoff, J. (2014). Exploring the impact of customer feedback on the well-being of service entities. Journal of Service Management, 25(4), 531-555.

Nyame-Mireku, M. (2012). Determinants of job satisfaction among hospital pharmacists and their intent to leave using herzberg's two-factor theory. ProQuest Dissertations \& Theses Global.

Olsen, M.D., West, J., Tse, E.C.Y. (2008). Strategic Management in the Hospitality Industry, $3^{\text {rd }}$ ed., New York: Prentice Hall.

Prasad, K., Wirtz, P. W., \& Yu, L. (2014). Measuring hotel guest satisfaction by using an online quality management system. Journal of Hospitality Marketing \& Management, 23(4), 445-463.

Prashar, P. (2017, June 1). The Impact of Online Reviews on the Hospitality Industry. Retrieved from https://www.hospitalitynet.org/opinion/4078144.htm

Radojevic, T., Stanisic, N., Stanic, N. 2015. "Ensuring Positive Feedback: Factors That Influence Customer Satisfaction in the Contemporary Hospitality Industry.” Tourism Management 51:13-21.

Rothe, H. F. (1948). Industrial psychology. Journal of Applied Psychology, 32(5), 565-567. 
Rothe, H.F., Brayfield, A. H. (1951, October). An Index of Job Satisfaction. Journal of Applied Psychology, 35(5), 307-311.

Rue, L. W., \& Byars, L. (2003). Management, skills and application. (10th ed.). New York: McGraw-Hill/Irwin.

Ryan, R. M., Deci, E. 2000. Intrinsic and extrinsic motivations: classic definitions and new directions. Contemp. Educ. Psychol. 25:54-67

Schlesinger, L. A. (1982). Quality of work life and the supervisor. New York: Praeger.

Staw, B. M., Sutton, R. I., \& Pelled, L. H. (1994). Employee positive emotion and favorable outcomes at the workplace. Organization Science, 5(1), 51-71.

Steelman, L., \& Rutkowski, K. 2004. Moderators of employee reactions to negative feedback. Journal of Managerial Psychology, 19: 6-18.

Sugio, S. (2010). Why ask the Guests? : An Examination of Mechanisms and Efficacy of Guest Feedback Used in Hotels in Perth. Retrieved from http://ro.ecu.edu.au/theses_hons/1233

Tavakol, M., \& Dennick, R. (2011). Making sense of Cronbach's alpha. International Journal of Medical Education, 2, 53-55. http://doi.org/10.5116/ijme.4dfb.8dfd

Vroom, V.H. (1964). Work and motivation, John Wiley and Sons, New York.

Waldersee, R., \& Luthans, F. (1994). The impact of positive and corrective feedback on customer service performance. Journal of Organizational Behavior, 15, 8395.

Weaver, A.D.; Watson, T.S.; Cashwell, C.; Hinds, J. \& Fascio, S. (2003). The effects of ability- and effort-based praise on task persistence and task performance. The Behavior Analyst Today, 4, 127-133.

Weiss, D.J., Dawis, R.V., England, G.W. and Lofquist, L.H. (1967), Manual for the Minnesota Satisfaction Questionnaire, Industrial Relations Center, University of Minnesota, Minneapolis, MN.

Wolf, E. J., Harrington, K. M., Clark, S. L., \& Miller, M. W. (2013). Sample Size Requirements for Structural Equation Models: An Evaluation of Power, Bias, and Solution Propriety. Educational and Psychological Measurement, 76(6), 913-934. 
Wong, S., Siu, V., Tsang, N., 1999. The impact of demographic factors on Hong Kong hotel employees' choice of job-related motivators. International Journal of Contemporary Hospitality Management 11 (5), 230-241.

Zapf, D., Holz, M., 2006. On the positive and negative effects of emotion work in organizations. European Journal of work Organism Psychology 15 (1), 1-28.

Zeithaml, V. A., \& Bitner, M. J. (2000). Services marketing: Integrating customer focus across the firm (2nd ed.). Boston: McGraw Hill. 